\title{
THE RE-COLLECTION OF THE
} RYERSON FASHION RESEARCH COLLECTION

\author{
by \\ Ingrid Masak Mida \\ BA, MAcc University of Waterloo 1985 \\ MRP \\ presented to Ryerson University \\ in partial fulfillment of the \\ requirements for the degree of \\ Master of Arts \\ in the Program of \\ Fashion
}

Toronto, Ontario, Canada, 2013

CIngrid Masak Mida 2013 


\section{AUTHOR'S DECLARATION FOR ELECTRONIC SUBMISSION OF A MRP:}

I hereby declare that I am the sole author of this MRP. This is a true copy of the MRP, including any required final revisions.

I authorize Ryerson University to lend this MRP to other institutions or individuals for the purpose of scholarly research.

I further authorize Ryerson University to reproduce this MRP by photocopying or by other means, in total or in part, at the request of other institutions or individuals for the purpose of scholarly research.

I understand that my MRP may be made electronically available to the public.

Ingrid Masak Mida 


\begin{abstract}
$\underline{\text { Abstract }}$
Christian Dior once said, "We invent nothing, we always start from something that has come before" (qtd. in Pochna 80). Historic garments can inform and inspire the present, offering up design potential for reinterpretations of styles of the past or serving as evidence of how fashion was worn and lived for material culture studies. Seeing a dress in a photo is a very different experience than feeling the weight of the fabric in hand, examining the details of cut, construction and embellishment, considering the relationship of the garment to the body or searching for evidence of how the garment was worn, used or altered over time. The Ryerson Fashion Research Collection is a repository of several thousand items acquired by donation since 1981, many of which are dresses and evening gowns dating from 1860 to 2000 . For several years, this collection lay dormant behind an unmarked door and was largely unknown by the student body. This project was initiated to understand the nature of the artifacts contained therein and is a first step in the process of refocusing and rebuilding the Collection for the future. The title "Re-collection of the Ryerson Fashion Research Collection" encapsulates the organizing principle for this practice-led interdisciplinary project, encompassing the intersection of material culture, curatorial process and collective memory in the identification of one hundred key items from the archive that reflect the breadth and history of the Collection itself.
\end{abstract}




\section{Acknowledgements}

The list of people that I could acknowledge for their role in this project is very long. I extend my appreciation to the many curators of museum and study collections who freely shared their knowledge with me and answered my many questions, especially Gillion Carrera at the Fashion Resource Centre at School of the Art Institute of Chicago, Cynthia Cooper at the McCord Museum, Kevin Jones at FIDM Museum, Dale Peers at the Seneca College Fashion Resource Centre, and Dr. Valerie Steele at FIT Museum. At Ryerson University, I offer my sincere thanks to Dr. Kimberly Wahl, Dr. Irene Gammel, and Dr. Lu Ann Lafrenz for their ongoing encouragement and patience. I also am grateful to Dr. Alison Matthews David for unlocking the unmarked door on the seventh floor of the library on February 10, 2012, and thereby revealing the Ryerson Fashion Research Collection to me. I also extend my thanks to Robert Ott, Chairman of the School of Fashion, for approving this project. And finally, I offer my love and deep gratitude to my husband Dan as well as my sons Mike and Jon for encouraging me in all that I do and cheering me on in moments of frustration and fatigue. 


\section{Dedication}

I dedicate this work to FCAD students in Ryerson University as a template for further research using the artifacts in the Ryerson Fashion Research Collection. I hope this project encourages fashion students everywhere to engage with objects as sources of design inspiration and material culture research. 


\section{Table of Contents}

Page

Introduction $\quad 1$

Chapter 1: Garments as Objects of Material Culture $\quad 4$

$\begin{array}{lll}\text { Chapter 2: } & \text { Study Collections } & 8\end{array}$

Chapter 3: Curation of the Ryerson Fashion Research Collection 13

Chapter 4: The Story of the Ryerson Fashion Research Collection 24

$\begin{array}{lll}\text { Chapter 5: } & \text { Conclusion } & 45\end{array}$

$\begin{array}{ll}\text { Tables } 1-17 & 50\end{array}$

$\begin{array}{ll}\text { Bibliography } & 66\end{array}$ 


\section{List of Tables}

Page

$\begin{array}{lll}\text { Table } 1 \quad \text { Selected Pre-1900 Artifacts } & 50\end{array}$

Table $2 \quad$ Selected Pre-1900 Artifacts continued 51

Table $3 \quad$ Selected Artifacts 1900-1909 52

$\begin{array}{lll}\text { Table } 4 \quad \text { Selected Artifacts 1910-1919 } & 53\end{array}$

Table $5 \quad$ Selected Artifacts 1920-1929 54

$\begin{array}{lll}\text { Table } 6 & \text { Selected Artifacts 1930-1939 } & 55\end{array}$

Table $7 \quad$ Selected Artifacts 1940-1949 56

$\begin{array}{lll}\text { Table } 8 & \text { Selected Artifacts 1950-1959 } & 57\end{array}$

Table $9 \quad$ Selected Artifacts 1950-1959 continued 58

Table $10 \quad$ Selected Artifacts 1960-1969 59

$\begin{array}{lll}\text { Table } 11 \quad \text { Selected Artifacts 1960-1969 continued } & 60\end{array}$

$\begin{array}{lll}\text { Table } 12 \quad \text { Selected Artifacts 1970-1979 } & 61\end{array}$

$\begin{array}{lll}\text { Table } 13 & \text { Selected Artifacts 1980-1989 }\end{array}$

$\begin{array}{lll}\text { Table } 14 & \text { Selected Artifacts 1980-1989 continued } & 63\end{array}$

$\begin{array}{lll}\text { Table } 15 & \text { Selected Artifacts Post-1990 }\end{array}$

$\begin{array}{lll}\text { Table } 16 & \text { Selected Artifacts Post-1990 Hats } & 65\end{array}$

$\begin{array}{lll}\text { Table } 17 & \text { Selected Artifacts } 2012 & 65\end{array}$ 


\section{Introduction}

The Ryerson School of Fashion opened in 1948, and since that time, a collection of garments, accessories and other items related to fashion has been available to instructors and faculty as a resource tool for the classroom. In 1981, formal written records for the Ryerson Costume Resource Collection ${ }^{1}$ were created and donations were accepted from staff, students and the public. Over the course of thirty-one years, several thousand garments, accessories, textile samples, patterns and other items were accepted into the Collection, and stored behind an unmarked door on the seventh floor of the Ryerson University Library. At the beginning of 2012, the Collection was not widely known among the student body and had become largely inaccessible due to degradation of the database and a lack of curatorial direction. This project was initiated to understand the nature of the artifacts contained therein.

In the book The System of Objects, Jean Baudrillard considered the relationship of a collection of objects relative to time when he wrote: "The deep-rooted power of collected objects stems neither from their uniqueness nor from their historical distinctiveness. It is not because of such considerations that the temporality of collecting is not real time but, rather, because the organization of the collection itself replaces time [sic]" (102). In accepting an object into a collection, it is set aside, protected and preserved, extending its biography outside its normal life cycle. The object becomes part of a group of objects that together as an entity represents the passage of time. During the course of this project, I was rediscovering the core of the archive and in so doing, unwrapping time and attempting to reveal the unwritten history of thirty-one years of artifacts donated to the School of Fashion at Ryerson.

\footnotetext{
${ }^{1}$ During the course of this project, the name was changed to the Ryerson Fashion Research Collection in order to better reflect the objectives of the School of Fashion.
} 
The materials for this research project encompassed the entire array of objects within the storage facility, including garments, accessories, fashion magazines, catalogues, patterns, pattern books and photographs, as well as the written records themselves, consisting of three binders of correspondence, one for each decade. This complex body of material is considered an archive, which Susan Pearce defines in her book Museums, Objects and Collections to consist of:

the entire holdings of a museum service and includes both the material - the collections themselves - and also the entire associated record... [which] ...can include letters, manuscript note books, annotated maps, offprints from journals, watercolours, photographs and field notes....To this should be added old packaging, boxing and labeling which sometimes survives to give crucial links between objects and provenances. (120)

To recollect means to recall to mind or to remember. A study collection, like a museum, is both a storehouse and a repository of memory, and collective memory is derived from the relationship of the objects to each other, through the act of selection by the curator in creating the collection. The title "Re-collection of the Ryerson Fashion Research Collection" encapsulates the organizing principle for this practice-led interdisciplinary project, encompassing the intersection of material culture, curatorial process and collective memory in the identification of one hundred key items from the archive that reflect the breadth and history of the Collection itself. The intent is to rediscover and remember what is important in this Collection, and in the process of doing so, refocus and rebuild the Collection for the future. This project also serves to contribute to the history of Canadian dress, which according to Alexandra Palmer, has "received extremely little academic attention and is still in its infancy" (“Canadian Couturiers" 4). In making that conclusion, Palmer mentions Ryerson's "holdings that include Canadian designs" and notes the lack of "publications that have 
appeared to contributed to the seminal documentation and analysis of historical Canadian dress" (5). 


\section{Chapter 1: Garments as Objects of Material Culture}

Material culture analysis is a research methodology that considers the relationship between objects and the "ways in which we view the past and produce our narratives of what happened in the past" (Pearce Museums, Objects 192). All objects that have been created by humans have a physical presence that is typically associated with a particular time and place. This materiality is part of the object biography and offers a non-textual link to the past. Museologist Susan Pearce described the way objects can reflect our identity: “Objects hang before the eyes of the imagination, continuously representing ourselves to ourselves and telling the stories of our lives in ways which would be impossible otherwise"(Museums, Objects 47). Using objects as primary evidence is a form of material culture research established by Jules David Prown in his 1982 article "Mind in Matter: An Introduction to Material Culture Theory and Method". A number of fashion scholars including Alexandra Palmer, Lou Taylor, Valerie Steele, and Francesca Granata have considered the significance of using actual garments in a multidisciplinary approach to the study of dress and are advocates of the Prown method of objectbased research.

Garments are important artifacts of material culture, providing evidence of the cultural and social history of a period since "fashion freezes the moment in an eternal gesture of theonly-right-way to be" (Wilson vii). Locating a specific garment on the timeline of fashion is generally possible through the evidence contained in the garment itself, using such clues as the cut, colour, silhouette, technology (e.g., type of closure mechanisms), labeling and fabrication (e.g., machine stitching vs. hand stitching) as well as the type and aging of the textile. However, garments can be a conflation of stylistic influences and caution must always be 
exercised in identifying and dating historic garments that might not conform to stylistic trends or are homemade (Palmer "Form Follows Fashion" 5).

Clothing is also a form of material memory, carrying the imprints of its intimate relationship to the body, the marks and stains of living, and the rips, strains and tears of movement. These marks provide evidence of a personal history in the garment's biography and "a single garment may be significant because of the relationship between its particular material form and the body that wears it" (Dant 86). The clothing that is kept beyond its fashionable life often has "symbolic qualities" and holds "personal memories" for the owner (De la Haye The Messels 14). In a poetic essay by Peter Stallybrass entitled "Worn Worlds: Clothes, Mourning and the Life of Things", the author describes how the clothes of his late colleague Allon White triggered sensory memories: "He was there in the wrinkles of the elbows, wrinkles that in the technical jargon of sewing are called 'memory'; he was there in the stains at the very bottom of the jacket; he was there in the smell of the armpits" (36).

Certain garments, particularly ones worn for special occasions like a wedding, may be kept as a treasured memory of an event or a loved one, and many women have garments that hang at the back of their closet, long out of fashion, but imbued with memories (Banim and Guy 217). As Katherine Brett, former curator of Textiles and Costume at the Royal Ontario Museum, wrote in the exhibition catalogue to Modesty to Mod: Dress and Underdress in Canada 1780-1967:

In every field of the household arts it is the treasured possession, and not the domestic chattel, that has been cherished and handed down from generation to generation for us to enjoy today. This is also true of clothing; it is the wedding dress or fine gown, worn once on a special occasion, that most often survives. (vi) 
Special occasion garments can be difficult to part with, and the owner may seek to prolong the biography of the object by selling or giving the item away to validate their investment in the piece (Lucas 18). Museum curators and managers of study collections can be overwhelmed with requests to accept donations of items that have emotional significance to the wearer, yet lack provenance or significance from a curatorial standpoint. In my experience, visiting a donor is a dance with grief, requiring an acute sensitivity to the complex nature of the grieving process and life's rites of passage.

When a garment is accepted into a study collection or museum and is divorced from its former owner, it is given a second life in a collection, stored in drawers, archival boxes or hanging storage. The item will never be worn or altered again, and its object biography is extended. Lou Taylor describes the altered nature of dress artifacts accepted into collections:

As static and empty vessels, they immediately become displaced 'objects' taking on a second life as venerable, valuable and treasured icons. They acquire a new mystique and a new life. Conserved at vast expense, they are wrapped and stored in dust-free, air-conditioned environments if they are lucky and then measured and catalogued by experts with extraordinary patience and specialized skills (Study of Dress History 18).

Although garments as artifacts embody "complex composites with multiple histories" (Palmer and Clark 9), this information is not always known, available or recorded when an item is accepted into a collection. Memories fade and time conflates. Yet, it is the role of the curator of fashion to place singular garments within a historical continuum to create "new patterns of chronology" and to "read time backwards, to read it from where we are standing, always in the present, acknowledging that this is our perspective" (De la Haye and Clark 162). In the absence of information from the donor, the curator must interpret the information provided by the garment itself and search for supplementary material to appropriately date and catalogue the item. 
The premise of a collection implies an act of choice. There must be a deliberate selection of "objects and specimens out from all the available material of the world", which are put "together in a way which renders the meaning of the group more than the sum of its individual parts" (Pearce Museums, Objects 66). This project was undertaken to reveal the nature of the objects in the Ryerson Fashion Research Collection as a first step in the refocusing and rebuilding of this collection for the future. 


\section{Chapter 2: Study Collections}

Historic garments can inform and inspire the present, offering up design potential for reinterpretations of styles of the past or serving as evidence of how fashion was worn and lived for material culture studies. Seeing a dress in a photo is a very different experience than feeling the weight of the fabric in hand, examining the details of cut, construction and embellishment, considering the relationship of the garment to the body or searching for evidence of how the garment was worn, used or altered over time. Both dress designers and historians can expand and enrich their research processes through object-based analysis.

One of the first study collections in North America was opened at the Brooklyn Museum in 1918. Prior to WWI, American designers had largely relied on Paris for inspiration and Stewart Culin, the curator of ethnology, sought to rectify that by offering designers access to garments and textiles in the museum. The Brooklyn Museum Guide to the Records of the

Department of Costumes and Textiles 1911-2004 indicates that Culin said at the time:

What these industries need during this critical time is an opportunity to study the basic source of inspiration. The time has come when they must do what designers of other great art cities of the past, including Paris, have always done - go back to the basic source of inspiration and follow their own inspirations derived from the material in terms of their own time and peoples. This is the only way art has ever found its way into industry.

From its inception, the costume and textile collection at the Brooklyn Museum was immensely popular with industry and a separate study room was soon designated for to facilitate access. The museum's ethnographic collection was also made accessible and visitors were allowed to handle and even try on the garments. According to the Brooklyn Museum Guide, an annual membership program was initiated in 1942 to support the department with two categories of membership. In 1947, donations from industry facilitated the creation of a 
design laboratory to support designers and technicians in the decorative arts and was renamed the Edwin C. Blum Design Laboratory in 1948. This lab was transferred to the Fashion Institute of Technology in 1973 where it still operates today.

Another early study collection of dress originated in New York in 1937 as a resource tool for the theatre community and was called the Museum of Costume Art. Housed in an office building in midtown Manhattan, this collection was also open to fashion designers, milliners, jewelers, and shoemakers. In 1944, the operation was assumed by the Metropolitan Museum of Art and was renamed The Costume Institute. Dorothy Shaver, president of Lord \& Taylor and head of the fundraising committee that facilitated this union in December 1944, was reported to have said (Today in Met History):

Today's announcement, that the Metropolitan Museum is taking steps to emphasize fashion as an art, is a history-making move in the life of American fashion. It recognizes the vitality and progressive spirit of the American fashion industries and it shows a desire on the part of a great museum to serve effectively these industries.

Initially, the prime users of the collection were industry professionals who engaged directly with the collection. Garments could even be tried on (a practice that was banned in museums in $1987^{2}$ ). In 1959, the Costume Institute became a separate curatorial department, and over time became more focused on scholarly research. According to curator Harold Koda, collection practices became oriented towards "the great aesthetic manifestations of any era" with an emphasis on provenance. The fragility of historic textile artifacts in the Costume Institute collection necessitated the limitation of access and Harold Koda said in a 2010 conference proceeding that: "There is a recognition that these pieces, every time they are handled, every time they are put on a mannequin, they are stressed".

\footnotetext{
2 In 1987, the Costume Society of America passed a resolution to discourage the wearing of museum artifacts, and this was adopted by international museum practice guidelines in 1993 as per ICOM "Guidelines for Costume". See also Taylor, The Study of Dress History, 47-50.
} 
In Toronto, The Royal Ontario Museum, which has over 50,000 objects in its costume and textile collection, at one time allowed faculty and students of Ryerson's School of Fashion access to its collection. For example, in the early years of the School of Fashion, illustration classes were conducted at the ROM. In 1979, ROM curator Mary Holford reported the acquisition and display of two items designed by Ryerson students in a ROM exhibit called "The Why and Wherefore of Clothes" (Reffes 4). In 1984, the CSO Newsletter reported that faculty member Sue Barnwell had created a series of three patterns of $18^{\text {th }}$ and $19^{\text {th }}$ century dresses in the ROM Collections and supervised a team of students who constructed prototypes thereof (15). This type of access at the ROM is no longer available to Ryerson students or faculty. ${ }^{3}$

Many leading fashion programs in universities in North America have study collections to which students, faculty and visiting scholars have access or can make appointments to examine historic and contemporary garments. They include: The School of the Art Institute of Chicago (SAIC) in Chicago, Parsons New School of Design as well as the Fashion Institute of Technology (FIT) in New York, Drexel University in Philadelphia, Rhode Island School of Design in Providence, Fashion Institute of Design and Merchandising (FIDM) in Los Angeles, Iowa State University in Ames, Kent State University Museum in Ohio, as well as University of Alberta in Edmonton and Seneca College in Toronto. The size and focus of these collections varies widely, with SAIC having the smallest collection of 300 artifacts that illustrate advanced design and construction from 1950 onwards to Kent State with 30,000 items that represent fashion from 1750 to today. Some collections include textiles, while others do not. The oldest collection within this group of university study collections is

\footnotetext{
${ }^{3}$ Access to the ROM Costume \& Textile Collection is presently restricted to invited scholars at the doctorate or post-doctorate level.
} 
Iowa State, which was founded in 1923 and includes 10,000 apparel and textile objects dating back as far as 1725 .

The primary purpose of a study collection is to educate and inspire. They may also serve to enhance teaching, research and outreach with the community through exhibition and display of artifacts (Marketti et al 255). While museums may have similar objectives, a study or resource collection differs from a museum collection in that handling of objects is expected. Since textiles and dress are inherently fragile, excessive handling may cause damage and accelerate decomposition, which may result in the need to limit access to preserve the garment for the future.

Some universities, like Kent State and FIT, have collections that rival that of museums and operate on that basis and the degree to which students are allowed access to all objects in the collection depends on the policies of the institution. Jean Druesedow, Director of the Kent State University Museum, believes in open access to the entire collection for students, faculty and visiting researchers and wrote in an email to me dated May 9, 2012:

My philosophy has always been - from the Costume Institute days to now - that students should have access to the very best in the collection. How can we inspire them by showing them lesser things? They need to know what excellence in design and fabrication is. So, our exhibitions try to present our best to the public all the while keeping the needs of students in mind. Kent is one of the few places where undergraduates have full access to the collections should they want it.

Open access is atypical and can mean different things at different institutions. At the SAIC, where no appointments are required, students are allowed to go into the storage area to browse, and may handle garments including putting them on mannequins and turning them inside out to study details of construction. At FIT, students may request to see items from the study collection, which consists of 2,000 artifacts and is kept separate from the museum 
collection. Students have to complete a research request in advance - asking for a specific designer or period - and the items are brought out to them on a rack. Garments may not be put on mannequins and may not be turned inside out. Although students and visitors to FIT are not required to wear gloves, they are closely supervised, and for some fragile pieces, the curatorial staff handles the garment. Access to the FIT Museum Collection is limited to curatorial staff. A study collection differs from a museum in that handling is expected, but the policies and practices differ by institution. In general, most university study collections attempt to follow ICOM guidelines for museum practice. 


\section{Chapter 3: Curation of the Ryerson Fashion Research Collection}

Textile Instructor Katherine Cleaver created the first written records for the Ryerson Costume Resource Collection in 1981. Included in that year's record is a photocopy of a handwritten memo entitled "Items of historic value in the Fashion Department of Ryerson Polytechnical Institute" by Beate Ziegert, Director of the School of Fashion. This memo lists fourteen entries identifying garments, textile samples, books of laces, patterns, drawings, historic dolls in period costume, fashion magazines, sewing machines and other items which had been collected "since 1948 when the Fashion Department was first set up". These items had been used as a teaching resource for the instructors in The Department of Food, Nutrition, Consumer and Family Studies, and included " 2 or 3 wooden file boxes of textile samples that had been collected by Miss Sarah Murdoch and Mrs. McKinley Scott since 1948". However, no accession numbers were assigned to these items in the records and it is not clear whether they ever formally became part of the department's collection or what happened to them. A Post-it note attached to the memo dated June 15, 1999, written in pencil asks: "Do garments exist or are they gone? $\mathrm{KC}$ '.

The first donation record with an accession number is a patterned textile with cotton weft and silk warp from China in brilliant blue and fuchsia pink that was fifty years old at the time of donation (1981.01.001). Subsequent records list the donation of textiles and garments including items accepted from Ryerson faculty and staff, prominent Toronto families and the public. Over time the Fashion Research Collection grew within The School of Fashion to several thousand items by 2009 when Professor Emeritus Katherine Cleaver retired. For three years, the Collection languished behind an unmarked door in the library, and by 2012, when this project was initiated, the database had become unusable, and there were racks and boxes 
of un-accessioned garments piled in the room. The number of items in the Collection at the beginning of this project is estimated to be approximately 3000 items, based on the " 1600 items of apparel, textiles and accessories" reported to be in the Collection in the 2007 media release for the exhibition "From Home Ec to High Tech: 60 Years of Fashion Education" plus donations accepted thereafter. However, the actual number of items on hand as of February 2012 could vary by plus or minus 1000 items since some of the items stored in the room had never been properly accessioned into the records.

In the absence of a written acquisition policy, the curatorial philosophy behind the Ryerson Fashion Research Collection was ascertained from clues in the records. In a letter dated October 14, 1981, Kathy Cleaver thanks Mrs. George Gooderham for her donation of dresses (1981.03.01 and 1981.03.02) and writes: "The petal-skirted (Royce) dress in particular will provide the students with an example of unique 1950's design techniques, while the chiffon dress is an excellent example of the draping and handling of chiffon fabric." In a letter to Miss Dowling dated September 28, 1987, Kathy Cleaver writes: "Mrs. Agnew has passed on to me your very nice donation of the cream wedding slippers. We are starting to build up a clothing collection here at Ryerson for the students to use as a study collection but we don't have things older than the 1940's so your gift is appreciated". In a printed copy of an email from Kathy Cleaver to a potential donor Ariella H. dated June 4, 2002: "I would like student garments for historic interest, to see what techniques were used, etc. They are also fun because they have a name attached (people give me things for the collection, but they often don't know exactly who made or owned them)." While this correspondence suggests an interest in collecting items for their historic value as well as for the purpose of demonstrating 
construction techniques, the large number of damaged, home-sewn and unremarkable garments in the Collection suggests that a passive collection policy was in place.

The public exhibition of garments from the Ryerson Fashion Research Collection has occurred only three times in the thirty-one year history. In June 1987, there was an exhibition of 1960s garments for two weeks in the Olive Baker Lounge on campus. In a Toronto Star article about this display, Kathy Cleaver was quoted as saying she "felt it was important to look back on the beginnings of this Canadian fashion consciousness" and that she had "recovered vintage garments from designers' storerooms and fashionable closets" (Hastings n.p.). In October 1989, there was an exhibition of early $20^{\text {th }}$ century garments called "Every hour an Occasion, Women's Dress 1900-1910" curated by Kathy Cleaver and Alan Suddon and designed by Robert Ott for display in the Olive Baker Lounge on campus. In November 2007, the School of Fashion celebrated its 40-year anniversary with an exhibition at the Design Exchange in Toronto called "From Home Ec to High Tech: 60 Years of Fashion Education at Ryerson". This display traced the evolution of the School of Fashion from its inception in 1948 and was researched and designed by students and supervised by Dr. Alison Matthews David. Unlike some study collections that actively exhibit the garments from their collection, the Ryerson collection was rarely on display and when this project was initiated, few students other than those taking the course in curation were aware of its existence. No scholarly research, prior to the commencement of this project, had involved the use of the artifacts from the Ryerson Fashion Research Collection.

Garments as artifacts may have complex histories with multiple owners or have undergone multiple alterations (Palmer and Clark 9), and in the absence of background information, "an article of clothing loses its associations and its social context. Ideally it 
should be accompanied by photographs of the item being worn, bills and receipts, and information on where it was made, where it was bought, how much it cost, where and when it was worn and so on" (Clark 231). When this type of information is recorded, it adds historical and social context to the wearing of the garment and can materially affect the relative importance and value of the item within a collection. Gathering background information was not a priority for the Ryerson Collection and most items have no more than the donor name and a very brief description of the artifact recorded beside an accession number. On file in some cases are letters from the donors and these letters offer small glimpses into donors' histories and motivations.

Some donors provided factual information, such as a donation to Ryerson from 1983 that included four items belonging to the donor's mother's grandmother that included an apron, hat, net and silk applique black shawl and white night cap. The donor, Lois T. simply wrote that: "The Roddick family came to Canada from Scotland and settled on a farm in eastern Ontario around 1835".

It is rare when donors can articulate their emotional connection to the garments. In an undated letter from 1988, Barbara M., the donor of several garments to Ryerson, described her passion for the items:

The wool suit from Britain was never worn very much, I somehow felt discouraged in it. Yet it has interesting lines, and was a good idea. Cannot date it, but believe it to be purchased from Eaton's Ensemble Shoppe. The cape is one of my loves - a bonded model Patrick de Barentzen. The seaming never fails to excite my admiration. This was purchased in 1957, and was worn - such luxury - over a bonded model navy blue Balenciaga suit. The cape came from Holt Renfrew through the always wonderful Miss Crispi.

This letter reveals so much about the owner's emotive investment in her garments. The suit was associated with feelings of disappointment, and the cape was associated with feelings of 
excitement and glamour. Such emotions often go unacknowledged and yet represent important aspects of the social biography of a garment. This type of contextual information enriches the garment's history, adding meaning even though it has been long separated from its former owner. Unfortunately, the specific items mentioned in this letter could not be located in the Collection.

It has also been my own curatorial experience that a significant number of objects offered to museums and study collections represent items reflective of grief and/or emotional significance for the donor, even if that is not evident on initial intake. There are notations in the records that mark certain pieces as having belonged to someone's deceased mother or grandmother. In a letter dated August 15, 1989, Betty T. writes about a photo of her mother in her wedding dress:

The picture I am enclosing is a very bad picture of Mother. She was married on 18 Feb. 1914 and I was born on 4 Dec. 1914. She looks ill - but look at the dress! How she ever made it I'll never understand. This dress must have been in her Trousseau. Look at the cut of the skirt! Don't forget there was no running water nor electricity....

In a letter dated April 29, 1995, Dolores D. writes about her mother's love of leather gloves and shoes:

I am sending these gloves that I offered to Ryerson. I hope that they are a suitable addition to your clothing collection at Ryerson. The gloves belonged to my mother Sara [surname omitted] of Leamington, Ontario. Mother was born in 1903 and died in 1989. She was a graduate of Victoria College, University of Toronto. I don't have any particular story about these gloves, but mother loved soft leather gloves and beautiful leather shoes.

Donating a garment can be an act of seeking immortality in that the donor seeks to give the item to "persons who are believed to be willing to care for them and in so doing honour and remember the donor" (Unruh qtd. in Pearce Museums, Objects, and Collections 63). A donor to Ryerson, Isabell M., confirmed her desire to have "a good home" for her 
grandmother's things, when she wrote on January 20, 2004: "I am delighted to be able to send you this 'petticoat', which belonged to the same woman whose two nightgowns you have my grandmother. Again, I don't need any income tax donation receipt ${ }^{4}-I^{\prime} m$ just glad to have these things have a good home."

One of the donors who contributed many of the rare historic pieces in the Fashion Research Collection was Alan Suddon. As well, Alan Suddon provided written appraisals of many of the pieces donated by others to Ryerson and his notes are interjected through the records prior to 2000. For example, in 1988, Suddon indicated his unequivocal approval of a donation of sixteen dresses from the 1950s by writing the comment in capital letters: "THIS IS A PARTICULARLY FINE DONATION OF 50'S AND 60'S DRESSES”. In another appraisal (1986.9.095), Suddon wrote:

This has a story to tell. It would appear to have been a dress, but the bodice has been cut off. It appears to have been home machine made - the fabric is heavily factory embroidered from hem to within a few inches of the waistband - Condition - soiled several fine darn mends - fabric disintegrating - I would say it is quite past being worn, even as a second class petticoat (value assigned \$30).

Alan Suddon was also a leading collector of historic dress in Toronto who amassed a sizeable personal collection, which included many rare and valuable items of dress, including couture items by Balenciaga, Balmain, Pierre Cardin, Jean Desses, Paquin, and Christian Dior as well as antique bridal gowns from the 19th century (Palmer in Couture \& Commerce 200). He died in 2000 at age 75, a few months after an exhibition of select pieces from his collection called

\footnotetext{
${ }^{4}$ Most donors received a tax receipt, and the records indicate that at least one donor was primarily motivated by tax receipts. This individual made two or more donations of a significant number of items each year from 19812009 , and the acceptance of items from this person burdened the collection with many damaged, soiled and unremarkable items, many of which were de-accessioned during the course of this project.
} 
200 Years of Toronto Fashion at Casa Loma. Alan Suddon's private collection was acquired by Kathy Cleaver in 2001.

The documentation of an object is considered almost as important as the object itself, because it provides critical information on the context, history and provenance of the item. According to The American Association of Museums Museum Registrations Methods Manual, the value of a collection "depends in the highest degree upon the accuracy and fullness of the records of the history of the objects which it contains" (2).

Proper registration of donations requires meticulous attention to detail and recordkeeping since information not properly documented on intake is lost. However, time is the enemy of collection managers (Marcketti et al 257). Recording the social biography of an item of clothing is time-consuming and an aspect of the documentation process considered least productive by some collection managers. At Ryerson, the management of the Fashion Research Collection was considered an adjunct duty to teaching and as a result the records are fragmentary and incomplete. Program modifications, the change in the status of the institution to a university in 1985 , and the addition of a graduate program in 2010 are other factors which would have impacted the time and funds available to support the collection.

Although the written records were scrutinized carefully to identify garments with provenance, many of those items were never located. One of the first donations to the Collection were two 1950s dresses from Mrs. George Gooderham, a prominent Toronto family (1981.3.01 and 1981.3.02) and only one dress has been found. In 2003, there was a donation of three evening gowns c. 1910 worn by Elizabeth Kimmerly of Vancouver to the coronation of King George V and related social events; two of these three gowns cannot be located (2003.06.01 and 2003.06.03). As well, two rare women's bicycling outfits from the early $20^{\text {th }}$ 
century (2002.06.04 and 2002.06.05), a hat by Jean Patou (2005.04.15) are also missing, as are many other pieces of lesser value or provenance. It is not known whether such items were loaned out, are lost, or missing for some other reason. Garments had initially been stored according to ICOM classification in terms of item type (dress, skirt, blouse, jacket), but over the course of time, as garments had been moved or borrowed, they had not been returned to those designated locations, leaving the room in disarray with no discernable method of organization. As well, there are also large numbers of artifacts without or separated from their accession numbers or identifying tags.

In 2005, The Brooklyn Museum Costume Collection faced a similar challenge on a much larger scale. Their costume collection had been stored in nine different areas of the museum, had minimal records, and an unknown number of artifacts with initial estimates varying between 35,000 to 70,000. Consulting Curator Jan Glier Reeder was brought in to supervise a Costume Documentation Project which sought to "clearly define the scope, content and quality of the museum's costume collection" by cataloguing, photographing, assessing and inventorying each item as well as identify "four thousand objects that represented some of the best examples from each object type in the collection”. Over the course of three years, a team of eleven people processed 23,834 records representing approximately 30,000 objects. This collection was transferred to the Metropolitan Museum of Art in January 2009 and is now known as the Brooklyn Museum Collection at the Metropolitan Museum of Art.

In the Ryerson Fashion Research Collection, the lack of information about the social biography of the artifacts in the records, the degraded database, and the state of the room when this project was initiated necessitated a systematic approach to editing the collection and 
identifying one hundred key artifacts. The process of examining each and every item focused on a linear progression through the room: drawer by drawer, cupboard by cupboard, rack by rack, box by box, and bin by bin. Although the bulk of items were stored on padded hangers or in inert metal containers, many had been stuffed into non-archival boxes or bins. Each container was a surprise, the outer markings often giving no hint as to what might be inside.

In order to create a collection narrative and to provide a fuller picture of the development and nature of the collection, a listing of important and valuable artifacts was created. The goal was to identify a sampling of items that reflected the breadth and history of the collection itself. According to Maria Luisa Frisa, "fashion curating is the exercise of a critical gaze, which recognizes the multiple traces, symptoms and fragments that are around us" (171). In this project, the curatorial process was largely instinctive, based on a visual assessment of the artifacts for their value in illustrating a historical period, construction technique or innovative design, or for their importance in terms of provenance as couture or a designer label.

This intuitive method of selection, the sheer volume of objects in storage and the absence of a usable database meant that multiple attempts were necessary to identify the most important one hundred artifacts. Tables were created to facilitate organization of groupings according to historic period (Tables 1-17). The information that was recorded for each artifact included: period, description (including label), accession number/location, reason for selection and donor. As items were identified, additional items were sought in order to fill in gaps. The initial goal was to select items that were in good or near-perfect condition and for which there were accession records. Multi-piece ensembles (a period dress with alternate bodices) or a pair 
of shoes were counted as one artifact. This project entailed numerous attempts to locate and construct a representative sample of the best pieces from each period.

An acknowledged weakness of this method is the high degree of curatorial judgment involved. The word curator is derived from the Latin curare, which means, "to care" and my selections reflect my personal bias towards the most valuable and aesthetically beautiful objects under my care. They are the core of the collection and represent the most important pieces from each historic period. I also used my knowledge of Canadian fashion history in choosing artifacts that represented Toronto retailers that no longer exist (such as Simpson's, Eaton's, Creeds) and Canadian designers that have passed away or have retired (such as Maggie Reeves and Marilyn Brooks), and while these items might not be as valuable as a couture label, they have significance as objects with a distinctly Canadian identity.

What is not reflected in the items selected is the significant percentage of contemporary items in the Collection that were homemade or without labels. The exact proportion cannot easily be discerned, but a rough estimate based on my handling of the items would approximate twenty to thirty percent. In the course of this project, many of these items were marked for de-accession, unless they represented historic pieces prior to 1950 or were representative of a particular construction technique taught in the design program at Ryerson.

The key constraint of choosing artifacts in near-perfect condition limited my choices substantially, as many of the more rare historic pieces are in poor or very poor condition. These items, many of which come from a time period when weighted silk was commonly used, are at the end of their object life from a conservation perspective. While some of them are exquisitely beautiful and represent techniques or styles of embellishment that are almost 
lost, some of these objects are literally crumbling into dust and accordingly those types of items were not included. 


\section{Chapter 4: The Story of the Ryerson Fashion Research Collection}

Discerning a narrative from a selection of one hundred garments and accessories is a creative process that is subject to interpretation. Curator Maria Luisa Frisa has suggested that the curatorial process can evolve from the "piecing together" of "fragments and clues" in order "to imagine a story" (173). Using my knowledge of Canadian fashion history as well as my intuition, the process of re-collecting the Ryerson Fashion Research Collection was iterative and imaginative, and it is self-evident that another curator might have chosen different objects. What is important is that the intent was to convey the historical breadth of the collection with pieces in perfect or near perfect condition, and the effort involved cannot be underestimated. Although such an exercise might appear to have been straightforward, it was not so in practice, especially given the absence of a searchable database. These one hundred items reflect what I believe is the core of the collection (Tables 1-17).

The clues contained within those artifacts were subtle, revealed in the smallest of details such as cut, fabric, embellishment, and labeling. The fragmentary nature of the records provided some ancillary information related to the donor, but rarely more. It was in the compilation of the tables that a story of the collection began to emerge. Some donor names appeared many times. Certain types of garments and certain periods had more or better quality items to choose from. Some periods reflected similar types of damage or conservation issues. Certain styles, colours and themes reappeared through the span of time. Some garments had become separated from their accession tags or were never accessioned properly and are denoted by FIC (Found In Collection).

Analysis of the archive was broken down into pre-1900 artifacts, the decades between 1900 and 1990, and post-1990 artifacts. This breakdown is meant only as a general guideline 
as significant stylistic changes did not happen in accordance with the end of a decade and most curators and appraisers recognize that most dress artifacts are not necessarily "iconic examples of a single period or style" (Palmer and Clark 9).

This work was not intended to serve as a comprehensive analysis of the stylistic trends of each period nor as an object analysis of each piece selected. This section focuses on broad trends in women's fashionable dress in Canada by decade in order to identify what might be missing in the Ryerson Fashion Research Collection and also to highlight the most unique and unusual items found therein. Each of the one hundred artifacts selected is worthy of in-depth research that is beyond the scope of this project. The primary goal was to identify the patterns revealed by the archive as a way of understanding the collective narrative represented therein.

\section{Selected Artifacts Pre-1900 (Tables 1-2)}

Historic garments that date prior to 1900 are rare and although the Collection has some, most of them are in poor condition. This is not surprising given that such pieces would have already been over one hundred years old when the collection formally began in 1981, which is also around the time when people in Toronto were becoming aware of the value of vintage clothing. $^{5}$

Prior to 1890 , most garments were made at home or by dressmakers (Kelcey 238). Most of the historic pieces that are in the Collection are a combination of machine and handstitched. As well, many are damaged or stained and would have likely been rejected by the Royal Ontario Museum or other private collectors. Another conservation issue related to the textiles of the late $19^{\text {th }}$ century and the early $20^{\text {th }}$ century was the use of weighted silks. Fabric

\footnotetext{
${ }^{5}$ Courage my Love, the first vintage clothing store in Toronto, opened in 1975. Seneca College in Toronto began their Fashion Resource Collection in 1985.
} 
was once sold by weight and unscrupulous merchants would dip silk in metallic salts, thereby increasing the weight. Since the metallic elements decompose at a different rate than the silk itself, the result is shattered silk. Initially the fabric splits and is irreparable. Over time the piece will literally turn to dust. Many of the items dating prior to 1920 in the Collection show this type of decomposition and little can be done to stop it.

One artifact selected from this period is a pair of perfect condition cream satin wedding slippers, which look as if they were hardly worn (Table 2, Item \#12). The donor, Ruth D. wrote:

These were wedding slippers of Mary Lawson of Caledon who wed Edward Dowling (a telegraph operator) of Bolton in either 1889 or 1890. There is no record of where the marriage took place - either Bolton or Caledon. Miss Lawson had a sister who lived in Buffalo so the slippers may have been purchased there. For the wedding, Miss Lawson wore a pale grey, long satin dress.

Another important artifact is a wire mesh and cotton tape sports bustle with the label “The Reversible Player Bustle", which is dated c.1880 (Table 2, Item \#7). A similar example is found in the Kyoto Costume Institute Collection (Fukai Fashion: A History 278). Sports like tennis were becoming more popular for ladies during this period and this wire bustle was intended to achieve a fashionable silhouette with a lighter substructure than those composed of horsehair or stiffly starched fabric. With the exception of this bustle, period undergarments such as corsets and crinolines are noticeably absent from the Collection. According to curator Eileen Collard, "crinolines were imported from the United States and Canadian women snapped them up as soon as they were available. By the late 1850s fashionable women and servant girls seldom appeared in a public place without a hoop under their dress skirts. Crinolines were manufactured in Montreal and Toronto by the early 1860s and women working on production lines earned an average of $\$ 3$ a week if they were hardworking 
individuals" ("The Intimate Woman " 5). Therefore, the lack of any such examples in the Collection indicates a significant gap.

A green plaid silk taffeta dress ensemble dated c.1860-1865 (Table 1, Item \#1) is the oldest historic piece in the collection, and is in remarkably good condition. The frontbuttoning bodice has black lace trim and pagoda sleeves, a stylistic feature of this period. The matching skirt is full with tucked pleats at the waist. Both are machine stitched. At this time, Toronto "was a muddy little city with a population of little over 50,000 and although it had fashionable air it was only in the first stage of its growth" (Batts 68). Another ensemble from this period, a royal blue corded silk dress ensemble with two bodices (Table 1, Item \#2) is not in nearly as good condition, although it too shows fine workmanship. It is accompanied by a notecard found on file that reads: "worn by forebearer of vendor in Penetanguishene and Toronto and purchased by Miss May Band for \$15 in 1978."

One of the most unusual sets of artifacts in the Fashion Research Collection is a group of carte de visite and cabinet cards donated by a single collector (Table 2, Item \#13). This rare set of photographs represents a tangible link between clothing and memory, and was chosen to reflect the range of items contained in the archive. Carte de visite and cabinet cards were albumen prints made from glass negatives, attached to stiff card backing usually printed with the photographer's name. In this medium, we can revisit the past to see the clothing that ordinary people wore in the latter half of the 19th century. This small cache of rare carte de visite and cabinet cards depicts Canadians photographed in studios from Toronto and other Ontario towns. In a few cases, names have been carefully written in blue ink just below the image or on the back of the card. The thick cards are yellowed at the edges and some have faded. There is a slightly musty smell -- the scent of the past. In studying these cabinet cards 
and carte de visites, my eye fixes on items of clothing that remind me of the specific historic pieces in the collection, including the greed plaid silk taffeta dress ensemble mentioned above. In those photographs, I feel like I am looking into the face of the wearer and seeing what is now a fragile artifact reborn. Through the image, the dress comes to life in a way that it will never be again. In an essay on "Photographs as Objects of Memory," Elizabeth Edwards states that photographs "belong to that class of objects formed specifically to remember", in that photographs "express a desire for memory and the act of keeping a photograph is, like other souvenirs, an act of faith in the future" (222). She concludes that "objects are links between past and present, and photographs have a double link as image and as material, two ontological layers in one object" (236).

In donating a photograph or a garment to a collection, the donor entrusts the curator with the care and keeping of that object into the foreseeable future. In the case of dress artifacts, a curator typically asks the donor for photos of the garment being worn, and with rare historic pieces, the existence of a photograph of the garment being worn is unlikely. Photographs of similar types of garments offer specific visual references to how that dress might have been worn and accessorized in the past, and in this way, the carte de visite by Toronto photographers can be used as a research tool by which to link images and material objects.

\section{Selected Artifacts 1900-1909 (Table 3)}

At the turn of the century, the ideal beauty was "a tall, queenly figure with a voluptuous hourglass shape, a long neck, and abundant upswept hair" (Routh 2). The clothing created to express this distinctly feminine silhouette was embellished with elaborate Edwardian frills, 
flounces and trims. In 1906, the Toronto Blue Book included an advertisement for The Robert Simpson Company Limited Toronto 2nd Floor Richmond Street, which describes "The Soul of a Gown":

A gown is a work of art or not, just as the modiste is an artist or not. If the dressmaker lacks inspiration, though she possess experience and skill, her work, nonetheless, falls short of that distinction which stamps a gown artistic. Our modistes are enthusiasts in their profession. Moreover, they are in constant touch with the fashion center of this continent - New York. Toronto women may, therefore, confidently expect to receive here the full benefit of such ideas as come only with experience in the metropolis.

Department stores and catalogue shopping opened up the range of fashionable goods available in Canada in the early part of the century. Nevertheless, labeled garments from this period are relatively rare according to Royal Ontario Museum curator Katherine Brett who wrote in 1967: "The labeling of garments does not seem to have begun here until the 1890's and many of the $20^{\text {th }}$ century clothes in the collection are without labels and their makers' names forgotten" (Modesty to Mod vii). Three items from this period from the Ryerson Collection that have store labels are thus particularly noteworthy.

Two blouses have labels from the T. Eaton Co., a retailer who played a significant role in the history of Canadian fashion. The Eaton's catalogue was in wide circulation across Canada and was commonly referred to as "the wishing book" (Routh 6). The Eaton's department store opened on December 8, 1869, at the southwest corner of Yonge and Queen Streets (Batts 68). Eaton's was the first to introduce mail order in 1885, and around the turn of the century, Timothy Eaton began to manufacture "dresses, cloaks, underwear, shirts, and shirtwaists for his own stores" (Routh 5).

A black silk bodice with lace jabot and high collar is labeled T. Eaton Co. and is in very good condition, especially given that weighted silk was common during this period 
(Table 3, Item \#16). A white lace/net blouse with $3 / 4$ sleeves and ruffles on the sleeve is labeled “T. Eaton Co. Toronto and Winnipeg” (Table 3, Item \#15). This donation came from Linda Lewis, a former chair of the School of Fashion, who made several significant donations to the Collection during her tenure.

Another important labeled item from this period includes an evening gown ensemble from L.M.Briens Importer, Toronto (Table 3, Item \#17) The black silk ensemble has two bodices, a long tiered lace skirt and a cape. One bodice is finely finished with delicate lace insets on the $3 / 4$ sleeves and the other more décolleté bodice, asymmetrically draped with lace, has short puffed sleeves. The lace on the sleeves is torn and the inner silk lining has shattered. There was a ladies tailor located on King Street called O'Brien's, which was considered a prestigious establishment which "catered to vice-royalty and ladies in diplomatic circles" (Routh 3), but further research would be required to establish whether the L.M. Briens label has any relationship to the O'Brien's shop.

A very fine example of an Irish crochet lace dress with $3 / 4$ sleeves, layered overskirt and bobble trim (Table 3, Item \#18) was chosen, since this type of crochet lace was made by hand and was popular in the early part of the century (Fukai Fashion: A History 316). The patterns and textures created by this crochet lace are suggestive of the Art Nouveau style.

\section{Selected Artifacts 1910-1919 (Table 4)}

The unnatural S-shaped silhouette for women in the prior decade evolved to a more narrow profile with high waists and narrow skirts in this period. Fashionable dresses were often richly coloured as a result of the influence of the Ballets Russes and modernist artistic movements. 
Dresses were often un-boned and unlined. This more revealing style of dress prompted a reader of The Hamilton Herald to write in 1912:

The freakish fashions which shamelessly display the physical rather than the innocent charms of young girls, are a disgrace, and put their mothers in an equally bad light. With large and amazing hats, transparent [shirt]waists, skirts reaching but a few inches below the knee, so tight that the figure is boldly displayed at every step, with stockings of the thinnest silk, our girls present a very improper spectacle. (qtd. in Collard 7)

Four white lawn or summer dresses (Table 4, Items \#22-25) have intricate cutwork, pin tucks, lace inserts and other delicate handwork. They are sheer and would reveal the body in the manner that the reader of The Hamilton Herald quoted above would have likely described as shocking.

One of the most important artifacts in the Collection in terms of historical provenance is a gown worn by Elizabeth Kimmerly to the Queen's Garden Party after the coronation of King George V on May 10, 1910 (Table 4, Item \#20). This black satin ensemble consists of two pieces: a black satin bodice with bows at the shoulder, asymmetric closure, black lace collar, cream lace cuffs and decorative embroidery; and a black satin skirt with net overskirt trimmed with cream cord scrollwork and coloured floral embroidery. Made in Paris for the owner before the coronation, this item marks a significant occasion in the relations between Canada and Britain. Further research into the background of Elizabeth Kimmerly and how her gown came to be donated by Joy Cherry is beyond the scope of this paper.

The influence of WW1 on women's fashion through the adoption of more practical and less restrictive styles can be seen in a woman's suit from this period (Table 4, Item \#26), which is labeled The Richieloy Limited, Belleville. This garment, made of sturdy wool with a full calf-length skirt, would have allowed more mobility than the hobble skirts worn earlier in the decade. Although the lining of the tunic length belted jacket has shattered, this suit is an 
important and rare artifact, since it is dated to 1919, the year women in Canada gained the right to vote when "An Act to confer the Electoral Franchise upon Women" came into effect according to the Parliament of Canada 1918.05.24.

\section{Selected Artifacts The 1920s (Table 5)}

The fast paced "Roaring 20s" were marked by simpler, more streamlined styles as women cut off their hair, abandoned restrictive undergarments and gave up high-buttoned boots (Routh 47). The simple drop-waist chemise dresses of the 1920 s were often elaborately beaded in intricate patterns on delicate materials like organza and silk. Over time, the weight of the beading often accelerates the decomposition of the fabric, resulting in splits and tears for many of dresses from this period. Although there were a number of beaded dresses from the 1920s donated to the Collection over the years, many of them are in very poor condition and thus were not selected as key artifacts. Nevertheless, an exception was made to this rule in selecting a cream satin wedding gown with a matching veil labeled Lanvin. Although the fabric on the dress has separated near the bust-line as a result of the weight of the beading and improper storage, the Art Deco beading is so rare and beautiful that this artifact was included (Table 5, Item \#27).

One garment from this period that has survived the assault of time is a black and peach silk flapper dress with deep $\mathrm{V}$ front revealing an underdress with beaded diamante trim and beaded epaulets at the shoulders (Table 5, Item \#29). This garment carries the label "Alice T. Williams, Peterborough, Ontario", likely a local dressmaker. 
None of the top Toronto dressmaker labels from this time period (Routh 52)-Clara Faulkner, Katherine MacInnes, Mrs. Eva Harrison, Madame Senior, Martha-were found in the Collection.

\section{Selected Artifacts 1930-1939 (Table 6)}

An undated photocopy of an Edmonton newspaper article from 1939 reads:

High noon was the hour chosen for a pretty wedding on Saturday, July 1 when at a ceremony performed in Leduc, Naomi (Meyme) Holland of this city became the bride of Clifford James Garvie also of Edmonton.... Chalk-white embroidered organdie fashioned into a gown featuring a long drifting skirt fitted bodice with tiny puffed sleeves was the frock the bride wore at her wedding. A ribbon sash of blue gave a note of contrast to the formal white frock, and her hat of white with soft veil of tulle, and white accessories completed her ensemble. She carried for her flowers a shower arrangement of red roses and white carnations.

This description of the dress worn by an Edmonton bride in 1939 accompanies a dress donated to the Ryerson collection in 1999 (Table 6, Item \#39). Although the dress is no longer white and the blue sash has gone missing, this clipping and the accompanying photo showing the bride and groom with their attendants add rich historical context to the garment. Worn for a summer wedding, the dress is light and relatively bare, and the photo shows the groom in uniform, not uncommon for wartime weddings.

There are a host of beautiful gowns from this period in the Collection showing the stylistic influences of Parisian designers Coco Chanel, Madame Vionnet and Elsa Schiaparelli as well as an element of escapist romanticism. According to fashion historian Eileen Collard "women of all ages expressed their desire to forget everyday problems by dressing up whenever the opportunity arose" (qtd. in Routh 74). Among the pieces selected from this decade is a rare Chanel evening gown c. 1937 (Table 6, Item \#33), in beige chiffon with silver metallic embroidery with black velvet ribbon trim. A cream-coloured silk jersey V-neck high- 
waisted evening gown with a red waist panel insert (Table 6, Item \#34) is cut on the bias and is stylistically similar to the designs of Elsa Schiaparelli. This unlabeled dress would have hugged the body like a glove, like many of the gowns of this period did.

\section{Selected Artifacts 1940-1949 (Table 7)}

Introduced in 1939, A61 regulations of The Wartime Price and Trade Board restricted manufacture of clothing with "yardage allowances and other elements regulated for individual garments" (Routh 89). Durable suits for women were popular because they were practical, since they "offered several mix-and-match possibilities, and could be easily changed from a day to an evening look. Suits, and their jackets, were described as being a Canadian tradition" (Turnbull Caton 260). The Collection includes a gray wool women's suit with double-breasted jacket with wide lapels, calf length skirt with kick pleats labeled Joan Rigby Toronto (Table 7, Item \#43). This Toronto boutique opened in the early 1940s at 54 Bloor Street West and was owned and operated by Joan Rigby and her husband. The shop had its own in-house designer for a line of suits and dresses (Palmer Couture and Commerce 293).

Evening gowns during the war years were less extravagant than in the prior decade. A black crepe evening gown with V-neck and short puffed sleeves with bow, peplum waist with back ties (Table 7, Item \#42) labeled Raphael Mack Hamilton reflects this wartime modesty. The notation in the records for this dress reads “worn by donor's sister Librarian Teacher's College Toronto".

Following the war, Christian Dior introduced his first collection on February 15, 1947 in Paris and presented a look that emphasized the bust, narrowed the waist and created fullness at the hips. At a time when French women were still being issued ration tickets, the overall 
impression of this collection was of femininity and elegant extravagance, and the contrast from the narrow silhouettes of the war years was startling. Dior said, "We were emerging from the period of war, of uniforms, of women-soldiers built like boxers. I drew women flowers, soft shoulders, fine waists like liana and wide skirts like corolla" (Cawthorne 109). Although outfits from this collection were prohibitively expensive, the collection was wildly successful and licensed versions soon appeared around the globe.

One of the most valuable pieces in the Collection from this post-war period is a rich burgundy velvet jacket with peaked pockets, cuff, and bodice detail with the label: CHRISTIAN DIOR - New York, Imported Irving Detroit (Table 7, Item \#45). This jacket from Irving Detroit is significant because of the number of protests that took place in Toronto against the extravagance of the New Look. On Dior's first trip to America, he encountered placards with the words "Down with the New Look," "Christian Dior Go Home" and "Burn Monsieur Dior" (Palmer Dior 27). On September 11, 1947, The Toronto Star published an article called "Counter-Revolution" in which it was reported: "The new styles are a method cooked up by the textile clothing manufacturers...to force women to buy whole new wardrobes. We urge all individuals and groups who support the boycott of long skirts to join the parade" (Palmer Dior 27). This "Protest Parade against Long Skirts" took place on September 13, 1947 on Yonge Street (Routh 96). It is likely that the original owner of this jacket travelled to Detroit to purchase it at Irving, but this cannot be confirmed since the item was donated anonymously. 


\section{Selected Artifacts 1950-1959 (Tables 8-9)}

The soft feminine styles of the 1950s are well represented in the Ryerson Fashion Research Collection, including several valuable Parisian couture pieces.

A pale green satin strapless ball gown, with floral spray at bust-line on a fitted boned bodice is narrow through the hem and supported by a crinoline underskirt. A pink satin overwrapped cummerbund extends into a train (Table 8, Item \#48). This exquisite numbered gown by PIERRE BALMAIN is named Marie Antoinette and would have been worn to the most formal of events on Toronto's social scene. Balmain was a label that only the elite could afford as Colin McDowell noted: “At his [Balmain] apogee as a purveyor of glamourous clothing to the rich in the 1950s and 1960s, he dressed queens, statesmen's wives, stars and virtually all the members of the international set" (91). This donor, Sommer Rotenberg, is listed with her husband in WHO'S WHO in Canada for 1975-76, and contributed several other couture gowns to the Collection in 1989.

A sleeveless black wool evening gown with scoop neckline threaded with velvet ribbon and diamante has a tulip hem and a matching bolero jacket and is labeled BALENCIAGA, 10 Avenue George, Made in France (Table 8, Item \#49). This gown has the narrower silhouette of Balenciaga and is likely from 1959 as it is consistent with the high waists of that year's Empire line. This donor contributed a significant number of couture pieces to the Collection in 1997.

A pink satin strapless evening dress with a boned bodice, draped full calf-length skirt and net underskirt has the label Made in Italy for Creeds (Table 9, Item \#52). This Toronto store, which originally opened in 1916, sold couture and in-house labels to the elite women of 
Toronto. This dress represents the classic feminine 1950s silhouette and shows the influence of Paris styles in the city.

A cream raw silk wedding dress with cap sleeves, shawl collar, 37 decorative buttons, dropped waist and full pleated paneled skirt labeled LISA Gowns looks rather unremarkable (Table 9, Item \#53), but is significant because it was worn by Mary Suddon, wife of Alan Suddon, who married at her father's home in Burlington (May 23, 1955). Alan Suddon was a prominent collector of historic clothing in Toronto and also appraised many of the pieces in the Collection. Her choice of wedding dress marks her as a woman who was aware of the stylistic trends of the day, but chose to wear a short dress that conveyed simple elegance as opposed to extravagance.

In the early part of the 1950s, "gloves, high-heeled pumps, and a hat were still essential daywear for any really stylish woman" (Routh 109). The Collection includes many hats from this period, from which two notable labels were chosen, including a brown net turban style hat with black beads by Miss Dior Created for Christian Dior as well as a very dramatic pink corded silk hat with black feather trim by Lily Hats, Miami (Table 9, Items \#54 and \#55).

Absent from the Collection are any garments from two leading Toronto designers from the 1950s, Federica and Tibor de Nagay, who were among the founding members of The Association of Canadian Couturiers ${ }^{6}$ (Palmer "Canadian Couturiers” 91).

\section{The 1960s (Tables 10-11)}

The 1960s were called a "Youthquake" by American Vogue editor Diana Vreeland (Hastings n.p.) and there were radical changes in the styles of women's dress during this time from prim

\footnotetext{
${ }^{6}$ Founded in 1954 to promote Canadian designs and textiles, this group was based on the idea of the Chambre syndicale de la couture in Paris and initially included fourteen members.
} 
lady-like attire to more youthful, casual, colourful outfits that included pants and mini-skirts. "Young women were no longer imitating their mother's dress style but were preferring and inventing a youthful one of their own that was interpreted by the international couturiers" (Palmer "Canadian Couturiers" 103). As well, prêt-a-porter or ready-to-wear emerged as an acceptable alternative to couture fashions. These changes seem to parallel the social revolutions of the period, including the changes in the roles of women from suburban housewives to workingwomen.

The Collection as a whole includes a large number of items from this period, perhaps because it was initiated in 1981 and by that time, donors were willing to part with the clothing that was twenty years old and no longer fashionable. Although paper dresses were a phenomenon in 1966-67 in Toronto (Routh 137), there are no paper dresses in the Collection.

The most valuable and important artifacts from this period are conservative in styling, which might in part reflect the more mature ages of those who could afford the couture pieces that were donated to the Collection. These include garments by Pierre Cardin, Nina Ricci, Jean Patou, Valentino, Givenchy and Christian Dior. This conservatism is consistent with the findings of Dr. Alexandra Palmer, senior curator of Textiles and Costume at the Royal Ontario Museum. In her analysis of Canadian consumption of couture in the 1950s, Palmer concludes: "Understatement, discretion, and notions of socio-economic value epitomized Toronto women's couture style and consumption patterns in the postwar years" (Couture and Commerce 292).

Four artifacts reflect a uniquely Canadian interpretation of the fashions of this period and merit further discussion as to the reason for their inclusion. 
A cream chiffon sleeveless Empire-waist floor length dress with metallic gold applique bodice (Table 11, Item \#63) is labeled David E. Rea Limited and dated 1966, the year the company won an EEDEE award for excellence in Ontario fashion design. David E. Rea was one of a group of apparel manufacturers that banded together in 1962 to promote their lines in the United States. This group also included Allenby Fashions, Highland Queen Sportswear, Norman Rogul Furs, Elen Henderson, Ruth Dukas and Claire Haddad (Routh 133). Although the Collection has several gowns from David E. Rea, there is only one gown designed by Ruth Dukas and none from the other designers.

A cream wool whipcord sleeveless Princess knee-length dress with cowl collar lined in cream silk blend with matching A-lined knee length coat with collar, $3 / 4$ sleeves, front bows and decorative 3" back band belt was designed by Robert K. Irwin (Table 11, Item \#69). Anne P., the donor of this item and other gowns by Robert K. Irwin, wrote a follow up letter that said: "Bob Irwin has offered to come in and confirm all the articles that were of his design. He also suggested that I take back the "evening dress" to place in auction. This would help cover some of our expenses, before the house is sold."

Toronto designer Maggy Reeves designed a brown and cream short sleeve day dress with floral applique (Table 11, Item \#64). This A-line short sleeve dress has simple feminine lines and the floral applique adds a bold, graphic element to the design. Maggy Reeves was called "the first lady of haute couture in Canada" and was known to work from "dawn to dusk creating new masterpieces and catering to her adoring clients desires" and her one-of-a-kind originals were popular "among Toronto's social elite" (Gostick “A Stitch in Time”). Also significant is that Ryerson University School of Fashion gives a financial assistance award for 
a garment that “most closely resembles Maggy Reeves original or Maggy Reeves' design philosophy in their second year of study in Fashion Design".

A romantic style of dress became popular towards the later part of the decade and Toronto designer Everett Staples designed an evening dress in green velvet with an Empirestyle waist with pink satin puffed sleeves embellished with pearls for Miss Taylor for the Jean Pierce label (Table 11, Item \#67). This shop was located on Eglinton Avenue and sold European, American and Canadian designs as well as the in-house designs of Everett Staples (Palmer Couture and Commerce 293).

\section{Selected Artifacts 1970-1979 (Table 12)}

Hemlines in the 1970s were "all over the place" and the "eclectic, free-form wardrobes of the late sixties continued to please at all levels" (Routh 148). The vibe of the decade is captured in a burgundy velour tunic dress with long sleeves and matching detachable hood designed by Marilyn Brooks (Table 12, Item \#73). Marilyn Brooks was a prominent Toronto designer in the 1970s, with retail boutiques across Canada as well as in San Francisco. Brooks was known for her sense of humour, adventure and creativity in design as well as for "pieces like the chain bra, black satin hot pants and her signature vinyl jumpsuit" (Canadian Encyclopedia). Brooks also designed uniforms and the Collection includes a gray nylon CN Tower jumpsuit uniform with silver metallic trim the Marilyn Brooks label.

Another jumpsuit uniform in the Collection is printed with small CN Towers in rust orange on gray cotton with a matching necktie in rust and is labeled Career Tex Career Wear by Sainthill Levine label (Table 12, Item \#74). The CN Tower opened in Toronto in 1976 and 
this uniform represents a significant landmark in Toronto history and also reflects the School of Fashion's objectives in offering courses in the design of functional apparel.

Quite a number of jumpsuits from this period were donated to the Collection, including a slate grey/blue wool jumpsuit with long sleeves and gathered cuffs by Saint Laurent Rives Gauche (Table 12, Item \#72).

Missing from the Collection are pieces representing prominent Canadian designers such as Alfred Sung, Claire Haddad, Linda Lundstrom, Edith Strauss and Michelle Lloyd.

\section{Selected Artifacts 1980-1989 (Tables 13-14):}

The 1980s have been described as decadent, characterized as a postmodern "eclectic blend of new wave fashion, Hollywood glitz, Japanese-influenced design, and fitness mania" (Routh 173). There was a new level of interest in fashion, marked by the production of fashion videos and the launching of Fashion Television in 1985. John Mackay, founding editor of Toronto Life Fashion magazine recalls this period:

The last year of the' 70 s and the first six years of the ' 80 s were a time that we'll never have again in our lifetime. The world embraced clothing and shopping in a way that [it] never [had] before. I think it made sense why you had the largest group of the population - the baby boomers in their millions - all reaching 30, all with some money, all looking, in their narcissism, to clothing. People who never before and never will again, look at a label, knew what they were wearing - and cared about what they were wearing. (qtd. in Fulsang 317)

A shiny metallic gold lame Edwardian style top with puffed sleeves and ruffles with a matching gold lame long gathered skirt by Pat McDonagh (Table 13, Item \#80) captures the essence of the 1980s evening look. Pat McDonagh was born in England, studied at Manchester University and the Sorbonne and came to Canada in the 1970s. According to her website biography, she is known for her "innovative textile techniques and youthful romanticism" and 
has designed gowns for celebrities and royalty. She is one of the founding members of the Fashion Design Council of Canada and has had a remarkable career as a Canadian fashion designer with 2010 marking her $40^{\text {th }}$ year in fashion.

Important labels from this period are represented by pieces from Missoni, Claude Montana, Chloe, Thierry Mugler, Donna Karan, Jean Muir and Mary McFadden. Missing from the Collection are notable Canadian designers Alfred Sung, Wayne Clark, Linda Lundstrom, as well as Ryerson grads Judy Cornish and Joyce Gunhouse of the Comrags label.

As the 1980s came to a close, the post-modern mixing of styles and influences allowed women to pick and choose from a range of fashionable options. Colin McDowell wrote at that time: "As the 1980s unfold, the signs are that the confusion of the previous two decades will continue. Women are now perfectly secure in their right to reject, their ability to choose and their power to control their appearance" (39).

\section{Selected Artifacts Post-1990 (Tables 15-17)}

After 1990, the post-modern recycling of trends in fashion makes the dating of clothing more of a challenge. The influence of grunge and Japanese designers are markers of the decade, but this anti-conformist look is largely absent from the Ryerson Collection. There are four notable pieces from Japanese designers that were donated after 2006: a Rei Kawakubo women's tailcoat (Table 16, Item \#88); a felted wool A-line dress with long sleeves by Issey Miyake (Table 16, Item \#90); a quilted silk, wool and tweed kimono style jacket from Kenzo (Table 15 , Item \#91); and a black and white pleated kimono style top with handkerchief hem also by Issey Miyake (Table 15, Item \#92). Three of these garments belonged to a single donor. 
In 2009, the Ryerson Fashion Research Collection accepted its largest donation from a single donor, consisting of over 700 garments and accessories belonging to Kathleen Kubas after she passed away in 2008 at the age of 70 . Some of these items are difficult to date, and more research will have to be done to date these pieces accurately, which is beyond the scope of this project. For example, a black jersey dress with dropped shoulders and shoulder pads, long inset sleeves gathered to a cuff, white satin collar, godet skirt labeled Jean Muir, Creeds (Table 14, Item \#82) was dated to pre-1990 since Creeds closed in 1990 as a result of bankruptcy.

Kathleen Kubas was a former model and actress before she became a grade 1 schoolteacher. She was also fond of designer labels, shopping at Holt Renfrew and Creeds, and she particularly loved hats. The pamphlet from her celebration of life (undated) notes that: Kathleen was known as "The Hat Lady" and her "hats reflected her personality - extravagant, yet elegant and fashionable". Her collection of hats also included hats by several milliners of note such as Phillip Treacy and Eric Javits, and accordingly five hats were selected as key items from this donation (Table 16). These hats are bold in design and are suggestive of a flamboyant and colourful personality who liked to be noticed.

The clothing of Kathleen Kubas also reflects her affinity for novel design. These are not the clothes of a wallflower. The colours of her wardrobe are vibrant, dominated by reds and purples, as well as fuchsia pink, but also punctuated by a balance of black, white and gray neutrals. The styling is distinctive with innovative cuts and lines of designers like Kenzo, Issey Miyake, Chloe, Donna Karan, Krizia, and Missoni. She clearly knew what she liked and what looked good on her tall, slender frame. 
As a collection of garments belonging to a single woman, this substantial donation gives insight into the purchasing practices of a woman who clearly loved expressing herself through fashion, even though she worked as a schoolteacher. Apparently Kathleen's husband received many FEDEX packages from US stores that were shipped to his office for her and some of the hat boxes still have written delivery instructions marked on the lids, with specific times indicated for delivery ("Celebrating Kathleen”). The high caliber of the labels and the near perfect condition of the pieces gives significant weight to the importance of this part of the Fashion Research Collection.

The last item selected for inclusion in the one hundred key artifacts of the Ryerson Fashion Research Collection is a black 2012 Tails Blazer from the F/W 2012 collection by Smythe (Table 17, Item \#100), a label designed by Andrea Lenczner \& Christie Smythe of Toronto. This item was sought out for donation by me in the fall as an addition to the Collection in order to acknowledge the success of Canadian designers who can serve as inspiration to Ryerson students.

The Smythe Tails Blazer is also a mirror to the past showing how design influences are recycled through time. The Ryerson Collection also includes a similarly styled 1880 fitted jacket with tails in black satin (Table 2, Item \#9) and a women's tailcoat designed by Rei Kawakubo (Table 15, Item \#88) more than 100 years later. The links between these three pieces provide an example of how garments can be used to educate students about fashion history and inspire students to make their own reinterpretations of the past. 


\section{Chapter 5: Conclusion}

A study collection is not a museum collection. The artifacts in a study collection are meant to be handled and are generally not as valuable or as rare as those owned by a museum. Many study collections initially accept all items offered for donation and at some point, when storage becomes an issue, there is a process of editing and a collection mandate is established.

The absence of a focused acquisition policy, curatorial direction and funding for the Fashion Research Collection at Ryerson University resulted in an accumulation of several thousand items by February 2012 which were stored in an unmarked facility on campus. Subsequent removal of hazardous, moth-eaten, badly soiled and damaged items, and the deaccession of unwanted items was initiated and occurred concurrently while this project was underway. What remains is a much smaller collection of garments, accessories and other artifacts that represent important artifacts of Canadian fashion history and would not be easily replaceable, marking a significant step in the process of re-establishing the Fashion Research Collection at Ryerson University.

The museum has been described by Andreas Huyssen as "both a burial chamber of the past - with all that it entails in terms of decay, erosion, forgetting - and as a site of possible resurrections" (qtd. by Palmer “A Bomb in the Collection” 41). Although the Fashion Research Collection at Ryerson University is not a museum, the collection of historic artifacts therein marks it as a site of memory. This project has sought to establish the nature of that collective memory through the selection and analysis of one hundred key artifacts from the archive. Collective memory is the idea that some memories are shared "based on common experience, learning, heritage, tradition, and more" (Crane 2). 
The objects that have been collected to date in the Ryerson Fashion Research Collection represent a shared memory of what donors felt was important to save and to remember. Given the passive collections policy, where all proffered donations were accepted, the accumulated items in the Collection would have reflected the attitudes and interests of the donors, most of whom were female. This group of donors chose to save women's special occasion dress.

Many of the items in the Collection were evening or bridal wear, emblems of the emotional ties that such special event clothing can have for the wearer who often desires to prolong the biography of that garment. Garments worn for a wedding or a gala event might only be worn a few times and thereafter hang for many years at the back of a closet before the owner considers how they might dispose of them. Similarly, garments once worn by a loved one who has passed away can represent the treasured memories of that person and be difficult to part with. Having such items accepted into a study or museum collection validates the acquisition and retention of that garment, because items in collections "share a perceived spiritual or intellectual worth and are guarded as such in a way that puts them in a special 'otherworld' category” (Pearce Museums, Objects, and Collections 33).

Most of the garments in the Ryerson Collection are ready-to-wear labels that would be affordable for the upper and middle-class consumer in Toronto. Such designers include both higher end labels such as Pierre Cardin, Balenciaga, Christian Dior, Balmain, Jean Patou, as well as more moderately priced in-house labels from retailers such as Holt Renfrew, Eaton's, Simpsons, and Jean Pierce. Although the average consumer might not have shopped at these stores for everyday items, special occasions might have offered the opportunity to justify the purchase of higher quality and more expensive items, with the emotional significance of such 
pieces leading the wearer to later donate the item instead of discarding it. As well, most of the garments in this Collection are conservative in styling, with the exception of the items donated by Kathleen Kubas. In part, this is a reflection of the passive collection policies of the past, but it also can be interpreted as a mirror of the conservative nature of the city of Toronto.

In this case study, one hundred key artifacts from the Collection were selected in order to rediscover and remember what is important in this archive, as a first step in the process of refocusing and rebuilding the Collection for the future. This subset of the collection reflected a shared memory of fashionable feminine special occasion dress for Toronto's conservative middle class over the span of more than a century. The many dresses therein are the "traces of lived experiences" (Sepulveda dos Santos 34), and represent shared values between the donors and the collection manager from 1981-2009. Many of the items in the Collection have truncated object biographies, since few items have photos, letters or notations in the records. Consequently, the memories of their owners, the occasions on which these garments were worn, and the feelings that they invoked have largely been lost, except as traces that exist in the marks, tears and stains that live in the folds.

The managerial practices of the past, including the absence of a formalized collection plan, has resulted in significant gaps in the Collection. With limited space, funding and support, a study collection needs a focused and directed plan to know what to collect in the future. For this project, gaps in the Collection were identified relative to the objectives of the School of Fashion to illustrate heritage, diversity and innovation in all programming.

The preservation of heritage is important in terms of including garments that document Canadian fashion history. While the Collection includes garments that illustrate the significant shifts in women's fashionable dress in Toronto from 1860 to the present, there are some 
marked gaps. As mentioned earlier, there is almost a complete absence of period corsets and crinolines, items that are often requested by students. Prominent Canadian designers, including Claire Haddad, Alfred Sung, Dean and Dan Caten, as well as Ryerson graduates Jeremy Laing, Tu Ly, Brian Bailey, and Lida Baday are not represented in this collection. Nor are there any iconic items from Canada's history such as a Hudson's Bay coat, and menswear items are significantly under-represented.

Innovation is conveyed through the collection of garments with inventive construction techniques or design. Much of what is in the Ryerson Fashion Research Collection is conservative in styling and construction and would not be considered innovative. Seeking donations of innovative international designers of their time, like Paul Poiret, Mariano Fortuny, Elsa Schiaparelli, Paco Rabanne, Azzedine Alaia or Alexander McQueen, would help to fill this gap.

Canada has a populace made up of diverse cultures, and most of what has been collected to date represents western dress. An effort to collect selected garments from aboriginal peoples and other cultures would offer students the opportunity to examine and be inspired by the techniques of construction, embellishment and design of other cultures.

In editing this collection, I have been entrusted with the shaping and organization of the material therein. The key to this process was the intent to reflect the goals of the School of Fashion in terms of representing heritage, diversity and innovation within the Fashion Research Collection. As a resource tool for students, faculty and visiting researchers, the objects in the collection must be relevant to the curriculum, support object-based research or serve as design inspiration. This project has served to help recollect and remember what is 
important in this collection as a first step in the process of refocusing and rebuilding the Ryerson Fashion Research Collection for the future. 
Re-Collection of the Ryerson Fashion Research Collection Table 1: Selected Pre-1900 Artifacts

\begin{tabular}{|c|c|c|c|c|}
\hline & Description (including Label) & $\begin{array}{l}\text { Accession } \\
\text { Number/Location }\end{array}$ & Reason for Selection & Donor \\
\hline 1 & $\begin{array}{l}\text { Green plaid taffeta front-button } \\
\text { bodice with pagoda sleeves and black } \\
\text { lace trim, hook and eye closure, } \\
\text { matching skirt with tucked detail, } \\
\text { machine stitched c. } 1860-65\end{array}$ & $\begin{array}{l}\text { 1990.3.001 A+B } \\
\text { Library } \\
\text { Flat storage east } \\
\text { Cabinet \#1 } \\
\text { Drawer \#1 }\end{array}$ & $\begin{array}{l}\text { Very beautiful and rare } \\
\text { historic piece } \\
\text { Oldest garment in the } \\
\text { collection } \\
\text { Very good condition }\end{array}$ & Helen S. \\
\hline 2 & $\begin{array}{l}\text { A. Royal blue corded day bodice with } \\
\text { pagoda sleeves and mandarin collar, } \\
\text { front piping and } 9 \text { fabric buttons with } \\
\text { Petersham belt } \\
\text { B. Matching evening bodice with } \\
\text { short puffed sleeves, } 9 \text { boning } \\
\text { channels, lined with white muslin, } \\
\text { Petersham belt } \\
\text { C. Full skirt with train, hook \& eye } \\
\text { closure } \\
\text { c. } 1860 \text { s }\end{array}$ & $\begin{array}{l}1997.03 .001 \\
\text { A+B+C } \\
\text { KHW66 } \\
\text { Box \#6 }\end{array}$ & $\begin{array}{l}\text { History (worn by } \\
\text { forebearer of vendor in } \\
\text { Penetanguishene and } \\
\text { Toronto and purchased by } \\
\text { Miss Mary Band for \$15 in } \\
\text { 1978) } \\
\text { Example of item with day } \\
\text { and evening bodice } \\
\text { Poor condition due to } \\
\text { deterioration of arm } \\
\text { shields }\end{array}$ & Alan Suddon \\
\hline 3 & $\begin{array}{l}\text { Navy velvet bodice lined in brown } \\
\text { cotton } \\
\text { Front buttons ( } 3 \text { buttons missing) } \\
9 \text { interior boning channels (boning } \\
\text { removed) } \\
\text { Pinked seams } \\
\text { Sleeves have } 3 \text { inch peaked cuffs }\end{array}$ & $\begin{array}{l}1997.03 .0014 \\
\text { KHW66 } \\
\text { Box \#104 }\end{array}$ & $\begin{array}{l}\text { Military styling } \\
\text { Beautiful buttons } \\
\text { Fine finishing detail }\end{array}$ & Alan Suddon \\
\hline 4 & $\begin{array}{l}\text { Black beaded evening capelet with } \\
\text { beaded floral design and beaded } \\
\text { fringe, lined in silk } \\
\text { Front hook \& eye closure } \\
\text { c. } 1850-60 \text { per donor notes } \\
\text { Seems more likely to be c. } 1890\end{array}$ & $\begin{array}{l}2006.04 .02 \\
\text { KHW } 66 \\
\text { Box \#101 }\end{array}$ & Exquisite beading & Carolyn P. \\
\hline 5 & $\begin{array}{l}\text { Brown and gold embroidered high- } \\
\text { necked dress with lace sleeve and } \\
\text { sheer overlay } \\
\text { Mother of pearl buckle trim on } \\
\text { bodice and tiered ruffled skirt } \\
\text { c. } 1880\end{array}$ & $\begin{array}{l}\text { 1986.9.094 } \\
\text { Library } \\
\text { Flat storage east } \\
\text { Cabinet \#1 } \\
\text { Drawer } 3\end{array}$ & $\begin{array}{l}\text { Very beautiful item } \\
\text { (fragile - skirt is starting to } \\
\text { separate from bodice) }\end{array}$ & Linda Lewis \\
\hline
\end{tabular}




\section{Re-Collection of the Ryerson Fashion Research Collection Table 2: Selected Pre-1900 Artifacts continued}

\begin{tabular}{|c|c|c|c|c|}
\hline & Description (including Label) & $\begin{array}{l}\text { Accession } \\
\text { Number/Location }\end{array}$ & Reason for Selection & Donor \\
\hline 6 & $\begin{array}{l}\text { Dark purple silk fitted long jacket } \\
\text { with front button closure } \\
\text { Matching full skirt with room for } \\
\text { bustle } \\
\text { Deep ruffle on skirt } \\
\text { c. } 1870-1880\end{array}$ & $\begin{array}{l}\text { 1997.3.020 } \\
\text { Library } \\
\text { Flat storage } \\
\text { Cabinet \#3 } \\
\text { Drawer \#15 }\end{array}$ & $\begin{array}{l}\text { Very small waist of skirt } \\
21 \text { inches } \\
\text { Skirt made for bustle } \\
\text { Fair condition }\end{array}$ & Alan Suddon \\
\hline 7 & $\begin{array}{l}\text { Wire tennis bustle } \\
\text { Label: The Reversible Player Bustle } \\
\text { c. } 1880\end{array}$ & $\begin{array}{l}\text { FIC } \\
\text { Library: File } \\
\text { cabinet (shoe box) }\end{array}$ & $\begin{array}{l}\text { Unusual example of a } \\
\text { sports bustle }\end{array}$ & Unknown \\
\hline 8 & $\begin{array}{l}\text { Brown velvet long jacket with bustle } \\
\text { and black beaded applique trim } \\
\text { Alternate jacket in Edwardian style } \\
\text { Gathered full skirt with } 7 \text { inch ruffle } \\
\text { Bustle jacket is boned with } 4 \text { boning } \\
\text { channels } \\
\text { Edwardian jacket is not boned } \\
\text { Skirt is lined in cotton } \\
\text { c. } 1880\end{array}$ & $\begin{array}{l}2008.03 .13 \\
\text { Library } \\
\text { Flat Storage } \\
\text { Cabinet \#7 } \\
\text { Drawer \#15 }\end{array}$ & $\begin{array}{l}\text { Very unusual example } \\
\text { with the alternate jacket } \\
\text { Suggests that owner liked } \\
\text { ensemble and made more } \\
\text { current style of jacket to } \\
\text { wear when the bustle back } \\
\text { was out of date and } \\
\text { Edwardian look emerged }\end{array}$ & $\begin{array}{l}\text { Unknown } \\
\text { (records } \\
\text { unclear) }\end{array}$ \\
\hline 9 & $\begin{array}{l}\text { Black fitted jacket with asymmetrical } \\
\text { neck closure, black lace detail at } \\
\text { sleeves and neck Long black tails; } \\
\text { Jacket is boned with } 8 \text { boning } \\
\text { channels; Seams are finely finished in } \\
\text { fuchsia. c. } 1880 \text { s }\end{array}$ & $\begin{array}{l}1999.5 .011 \\
\text { KHW66 } \\
\text { Box \#103 }\end{array}$ & $\begin{array}{l}\text { Menswear styling of a } \\
\text { women's garment } \\
\text { Interior finishing is very } \\
\text { beautiful }\end{array}$ & Bob G. \\
\hline 10 & $\begin{array}{l}\text { Forest green silk day dress with } \\
\text { cream lace inset neckline trimmed in } \\
\text { pink satin ribbon and dark green } \\
\text { velvet ribbon, long two-piece ruched } \\
\text { sleeves, with banded waist and waist- } \\
\text { tucked skirt } \\
\text { c. } 1895\end{array}$ & $\begin{array}{l}1986.9 .93 \\
\text { KHW66 } \\
\text { Box \#9 }\end{array}$ & $\begin{array}{l}\text { Beautiful example of } \\
\text { Edwardian style dress in } \\
\text { very good condition }\end{array}$ & Linda Lewis \\
\hline 11 & $\begin{array}{l}\text { Black beaded evening cape } \\
\text { Denim lined in silk } \\
\text { c. } 1885-1895\end{array}$ & $\begin{array}{l}\text { FIC } \\
\text { Library west } \\
\text { File Cabinet \#6 }\end{array}$ & $\begin{array}{l}\text { Exquisite and rare } \\
\text { accessory }\end{array}$ & Unknown \\
\hline 12 & $\begin{array}{l}\text { Cream satin wedding slippers } \\
\text { c. } 1889-1890\end{array}$ & $\begin{array}{l}\text { 1987.4.01AB } \\
\text { Library file cabinet }\end{array}$ & $\begin{array}{l}\text { Beautiful shoes in very } \\
\text { good condition }\end{array}$ & Ruth D. \\
\hline 13 & $\begin{array}{l}\text { Carte de visite c. } 1860-1920(466) \\
\text { Postcards and photos c. } 1880-1930 \\
(525)\end{array}$ & $\begin{array}{l}\text { 2002.04.xxx } \\
\text { KHW66 }\end{array}$ & $\begin{array}{l}\text { Rare collection of carte de } \\
\text { visite many of which } \\
\text { include names of Toronto } \\
\text { photography studios }\end{array}$ & Pat R. \\
\hline
\end{tabular}


Re-Collection of the Ryerson Fashion Research Collection

Table 3: Selected Artifacts 1900-1909

\begin{tabular}{|c|c|c|c|c|}
\hline & Description (including Label) & $\begin{array}{l}\text { Accession } \\
\text { Number/Location }\end{array}$ & Reason for Selection & Donor \\
\hline 14 & $\begin{array}{l}\text { Women's parasols (2) c.1900-1915 } \\
\text { A. Cream lace and cotton parasol } \\
\text { with carved handle (fair condition) } \\
\text { B. Black silk parasol, cream ribbon } \\
\text { embroidery and lace trim, wooden } \\
\text { handle }\end{array}$ & $\begin{array}{l}\text { 1989.2.1 } \\
\text { KHW66 } \\
\text { A. Box \#109 } \\
\text { B. shelf }\end{array}$ & $\begin{array}{l}\text { Period Accessories } \\
\text { Gendered decorative object - } \\
\text { non-functional }\end{array}$ & Helen S. \\
\hline 15 & $\begin{array}{l}\text { White lace } / \text { net } 3 / 4 \text { sleeve blouse with } \\
\text { ruffles on sleeve } \\
\text { Label: T.Eaton Co. Toronto and } \\
\text { Winnipeg } \\
\text { c. } 1900-1910 \text { (appraisal refers to } 1901 \\
\text { Eaton's Catalogue) }\end{array}$ & $\begin{array}{l}\text { 1986.0.087 } \\
\text { Library } \\
\text { Cabinet \#1 } \\
\text { Drawer \#2 }\end{array}$ & $\begin{array}{l}\text { Canadian retailer } \\
\text { Very rare labeled piece } \\
\text { Example of women's adoption } \\
\text { of blouses with suits }\end{array}$ & Linda Lewis \\
\hline 16 & $\begin{array}{l}\text { Black silk bodice with lace jabot. } \\
\text { Front bodice has tucked dtail and } \\
\text { high collar. Lace jabot has come } \\
\text { unattached and should be resewn. } \\
\text { Label: } \text { T. Eaton Co. } \\
\text { c. } 1900-1910\end{array}$ & $\begin{array}{l}2008.03 .07 \\
\text { KHW66 } \\
\text { Box \#103 }\end{array}$ & $\begin{array}{l}\text { Canadian retailer } \\
\text { Very rare labeled piece } \\
\text { Very good condition }\end{array}$ & $\begin{array}{l}\text { Unknown } \\
\text { (records are } \\
\text { unclear) }\end{array}$ \\
\hline 17 & $\begin{array}{l}\text { Black two-piece evening gown with } \\
\text { two bodices } \\
\text { A. Evening Bodice - short sleeve } \\
\text { lightly boned black lace and silk } \\
\text { bodice with scoop neck and short } \\
\text { sleeves (silk has shredded), } \\
\text { Petersham belt } \\
\text { B. Bodice } 1 \text { - black silk bodice with } \\
\text { square neckline and } 3 / 4 \text { sleeves with } \\
\text { lace insets, lightly boned, Petersham } \\
\text { belt with label: } \text { L.M. Brien Importer, } \\
\text { Toronto } \\
\text { C. Black silk skirt with train and } \\
\text { layers of tiered lace, net and ruffled } \\
\text { underskirt } \\
\text { D. Black silk cape with front frog } \\
\text { closure }\end{array}$ & $\begin{array}{l}\text { 2001.06.01 ABCD } \\
\text { KHW66 } \\
\text { Box \#3 }\end{array}$ & $\begin{array}{l}\text { Rare labeled piece from } \\
\text { leading Toronto retailer }\end{array}$ & Alan Suddon \\
\hline 18 & $\begin{array}{l}\text { White Irish crochet summer dress } \\
\text { with layered overskirt with bobble } \\
\text { trim } \\
3 / 4 \text { sleeves with bobble trim } \\
\text { c. } 1908\end{array}$ & $\begin{array}{l}2009.04 .071 \\
\text { KHW66 } \\
\text { Box } 106\end{array}$ & $\begin{array}{l}\text { Summer day silhouette } \\
\text { Exquisite textile and finishing }\end{array}$ & Karen M. \\
\hline 19 & $\begin{array}{l}\text { Men's formal evening suit: Black } \\
\text { wool tails and pant suit, Jacket } \\
\text { cutaway with very fine } \\
\text { tailoring/stitching on lining; Pants } \\
\text { high cut with front button closures } \\
\text { with satin trim down side of pant legs } \\
\text { c. } 1909-1910\end{array}$ & $\begin{array}{l}2007.01 .75 \\
\text { KHW66C } \\
\text { Rack \#1 }\end{array}$ & $\begin{array}{l}\text { Menswear } \\
\text { Offered as comparison to } \\
\text { women's wear (Historic } \\
\text { bodice and also Yohji } \\
\text { Yamamoto) }\end{array}$ & $\begin{array}{l}\text { Emmy (no } \\
\text { last name } \\
\text { given) }\end{array}$ \\
\hline
\end{tabular}


Re-Collection of the Ryerson Fashion Research Collection

Table 4: Selected Artifacts 1910-1919

\begin{tabular}{|c|c|c|c|c|}
\hline & Description (including Label) & $\begin{array}{l}\text { Accession } \\
\text { Number/Location }\end{array}$ & Reason for Selection & Donor \\
\hline 20 & $\begin{array}{l}\text { Black satin dress ensemble, black } \\
\text { bodice and skirt, overlaid with lace } \\
\text { and net, trimmed with cord } \\
\text { scrollwork and embroidery, bows at } \\
\text { shoulder, cream lace cuffs. Boned } \\
\text { and lined. } \\
\text { Worn by Elizabeth Kimmerley } 1910 \\
\text { Paris }\end{array}$ & $\begin{array}{l}2003.06 .002 \mathrm{~A}+\mathrm{B} \\
\text { KHW66 } \\
\text { Box \#8 }\end{array}$ & $\begin{array}{l}\text { Provenance and rarity } \\
\text { Made for the owner in Paris } \\
\text { for the coronation of King } \\
\text { George V in May } 1910\end{array}$ & Joy Cherry \\
\hline 21 & $\begin{array}{l}\text { Peach satin and pale orange silk } \\
\text { v-neck gown with rosettes (interior } \\
\text { Petersham belt) and weighted hem } \\
\text { Label: Edgley's Limited, The } \\
\text { Children's Shop, 576 King Street, } \\
\text { Toronto } \\
\text { c.1915 }\end{array}$ & $\begin{array}{l}\text { 1999.99.001 } \\
\text { KHW66 } \\
\text { Box \#8 }\end{array}$ & $\begin{array}{l}\text { Beautiful example of period } \\
\text { gown }\end{array}$ & Anonymous \\
\hline 22 & $\begin{array}{l}\text { White cotton picnic dress with double } \\
\text { collar, elbow length sleeves and } \\
\text { tiered ruffled skirt } \\
\text { c. } 1915\end{array}$ & $\begin{array}{l}\text { 2004.01.02 } \\
\text { KHW66C }\end{array}$ & Period silhouette & Jane D. \\
\hline 23 & $\begin{array}{l}\text { White lawn dress with long sleeves, } \\
\text { front buttons, pin tucks and lace } \\
\text { inserts } \\
\text { c. } 1917 \text { (dated by Alan Suddon) }\end{array}$ & $\begin{array}{l}1999.6 .014 \\
\text { KHW66 } \\
\text { Box \#4 }\end{array}$ & Summer day dress/silhouette & Alan Suddon \\
\hline 24 & $\begin{array}{l}\text { White cutwork cotton summer dress } \\
\text { with layered overskirt trimmed in } \\
\text { lace } \\
\text { 3/4 sleeves, V neck, scalloped hem } \\
\text { Slight stain on skirt front } \\
\text { Back closure with snaps c.1915-1918 }\end{array}$ & $\begin{array}{l}\text { FIC } \\
\text { KHW66 } \\
\text { Box } 107\end{array}$ & $\begin{array}{l}\text { Summer day dress/silhouette } \\
\text { Exquisite textile and finishing }\end{array}$ & Unknown \\
\hline 25 & $\begin{array}{l}\text { White organdy lawn dress with long } \\
\text { sleeves, bolero-like detail on bodice, } \\
\text { tiered skirt c. } 1915\end{array}$ & $\begin{array}{l}1986.9 .92 \\
\text { KHW66 } \\
\text { Box \#4 }\end{array}$ & Summer day dress/silhouette & Linda Lewis \\
\hline 26 & $\begin{array}{l}\text { Brown wool ladies suit with shawl } \\
\text { collar, belted waist and } 5 \text { button cuffs } \\
\text { on sleeves (lining has shattered) } \\
\text { Label: The Richieloy Limited, } \\
\text { Belleville c. } 1919 \\
\text { Angle length skirt is gathered at } \\
\text { waist, side snap closures, inner belt } \\
\text { and also outer belt and button detail } \\
\text { at hem }\end{array}$ & $\begin{array}{l}\text { FIC } \\
\text { KHW66 } \\
\text { Rack \#1 }\end{array}$ & $\begin{array}{l}\text { Rare example of women's suit } \\
\text { Tag on sleeve says "1919 } \\
\text { Wool suit as is } \$ 54 \text { " }\end{array}$ & Unknown \\
\hline
\end{tabular}


Re-Collection of the Ryerson Fashion Research Collection Table 5: Selected Artifacts 1920-1929

\begin{tabular}{|c|c|c|c|c|}
\hline & Description (including Label) & $\begin{array}{l}\text { Accession } \\
\text { Number/Location }\end{array}$ & Reason for Selection & Donor \\
\hline 27 & $\begin{array}{l}\text { A. Cream satin wedding gown with } \\
\text { short sleeves, high waist. } \\
\text { Embellished with silver beading } \\
\text { c. } 1925-1930 \\
\text { B. Matching beaded wedding } \\
\text { headpiece and Veil labeled Lanvin } \\
\text { c. } 1925-1930\end{array}$ & $\begin{array}{l}\text { FIC (2007) } \\
\text { KHW66 } \\
\text { Box \#2 }\end{array}$ & $\begin{array}{l}\text { Couture gown/beading } \\
\text { (Dress in very poor } \\
\text { condition) } \\
\text { Exquisite beading on gown } \\
\text { and headpiece }\end{array}$ & $\begin{array}{l}\text { Unknown } \\
\text { (possibly } \\
\text { Shelagh } \\
\text { Stewart) }\end{array}$ \\
\hline 28 & $\begin{array}{l}\text { Black sleeveless silk dress with } \\
\text { dropped waist and lace overlay with } \\
\text { ribbon detail. Pink ombre inset at } \\
\text { thigh level is visible through lace. }\end{array}$ & $\begin{array}{l}\text { FIC (2001) } \\
\text { KHW66 }\end{array}$ & $\begin{array}{l}\text { Fair condition } \\
\text { Ombre silk is split } \\
\text { Lace at shoulders is fragile }\end{array}$ & Unknown \\
\hline 29 & $\begin{array}{l}\text { Black and peach silk flapper dress, } \\
\text { deep V front reveals underdress } \\
\text { with beaded rhinestone trim, beaded } \\
\text { epaulets at shoulders } \\
\text { Label: Alice } T \text {. Williams, } \\
\text { Peterborough, Ontario c.1926- } \\
1929\end{array}$ & $\begin{array}{l}1989.4 .5 \\
\text { KHW 66C } \\
\text { Rack \#1 }\end{array}$ & $\begin{array}{l}\text { Labeled piece } \\
\text { Period silhouette and styling } \\
\text { in good condition }\end{array}$ & Norah C. \\
\hline 30 & $\begin{array}{l}\text { Black net dress with short sleeves, } \\
\text { scalloped collar and peblum waist, } \\
\text { tiered skirt with two underbodices } \\
\text { (one corset style and one vest style } \\
\text { with square neckline) c. } 1920 \text { s }\end{array}$ & $\begin{array}{l}\text { 1999.5.001 } \mathrm{A}+\mathrm{B}+\mathrm{C} \\
\text { Library west } \\
\text { Flat Cabinet \#5 } \\
\text { Drawer \#2 }\end{array}$ & $\begin{array}{l}\text { Multiple bodices } \\
\text { Unusual styling } \\
\text { Good condition relative to } \\
\text { age }\end{array}$ & Bob G. \\
\hline 31 & $\begin{array}{l}\text { Beige lace flapper dress, long } \\
\text { sleeves with frilly cuffs, scoop neck } \\
\text { with tortoise shell buckle on L } \\
\text { shoulder, peach underslip } \\
1925\end{array}$ & $\begin{array}{l}\text { 1989.4.4 } \\
\text { Library Flat } \\
\text { Cabinet \#6 } \\
\text { Drawer } 7\end{array}$ & $\begin{array}{l}\text { Fair-good condition } \\
\text { Small stain on underslip }\end{array}$ & Norah C. \\
\hline 32 & $\begin{array}{l}\text { Black textured weave silk jersey in } \\
\text { checkerboard pattern evening coat } \\
\text { with beige silk lining } \\
\text { Collar folds over and can snap } \\
\text { down } \\
\text { c. } 1920 \text { s }\end{array}$ & $\begin{array}{l}1993.5 .14 \\
\text { KHW66C } \\
\text { Rack \#1 }\end{array}$ & $\begin{array}{l}\text { Unusual design } \\
\text { Beautiful texture } \\
\text { Period silhouette }\end{array}$ & $\begin{array}{l}\text { Ogden } \\
\text { Family }\end{array}$ \\
\hline
\end{tabular}


Re-Collection of the Ryerson Fashion Research Collection Table 6: Selected Artifacts 1930-1939

\begin{tabular}{|c|c|c|c|c|}
\hline & Description (including Label) & \begin{tabular}{|l|} 
Accession \\
Number/Location
\end{tabular} & Reason for Selection & Donor \\
\hline 33 & $\begin{array}{l}\text { Beige and silver metallic } \\
\text { embroidered evening dress } \\
\text { CHANEL c. } 1937\end{array}$ & $\begin{array}{l}2001.06 .28 \\
\text { Box 1 }\end{array}$ & Couture gown & $\begin{array}{l}\text { Alan } \\
\text { Suddon }\end{array}$ \\
\hline 34 & $\begin{array}{l}\text { Cream V-neck bias cut silk jersey } \\
\text { short sleeved high-waisted evening } \\
\text { gown with red waist panel on bias } \\
\text { and gathered bust darts } \\
\text { Back metal zipper insert c.1930s }\end{array}$ & $\begin{array}{l}1995.2 .1 \\
\text { KHW66 C } \\
\text { Rack 1 }\end{array}$ & Bias cut & $\begin{array}{l}\text { Ogden } \\
\text { Family }\end{array}$ \\
\hline 35 & $\begin{array}{l}\text { Blue and silver metallic crepe } \\
\text { evening dress with short sleeves, } \\
\text { side gathers, side zipper (metal) and } \\
\text { back bow } \\
\text { Label: Vogue Couturiers c.1930s }\end{array}$ & $\begin{array}{l}2006.01 .07 \\
\text { KHW66C } \\
\text { Rack 1 }\end{array}$ & $\begin{array}{l}\text { Beautiful fabric } \\
\text { Home sewing } \\
\text { Bias cut construction }\end{array}$ & Karen M. \\
\hline 36 & $\begin{array}{l}\text { Pumpkin yellow taffeta evening } \\
\text { dress, matching waist-length jacket } \\
\text { with puff sleeves and self fabric } \\
\text { buttons c. } 1930 \text { s }\end{array}$ & $\begin{array}{l}\text { 1993.3.2 A+B } \\
\text { KHW } 66 \\
\text { Box \#2 }\end{array}$ & $\begin{array}{l}\text { Brilliant colour } \\
\text { Shows transition to new } \\
\text { silhouette }\end{array}$ & Ethel A. \\
\hline 37 & $\begin{array}{l}\text { Dusty rose long dress with } \\
\text { sweetheart neckline and tiered } \\
\text { ruffled skirt. Missing pink \& purple } \\
\text { velvet sash. }\end{array}$ & \begin{tabular}{|l} 
FIC \\
KHW66C \\
Rack 1
\end{tabular} & $\begin{array}{l}\text { Tag reads Made in Toronto } \\
\text { for Jean Crawford to wear at } \\
\text { age } 14 / 15\end{array}$ & Unknown \\
\hline 38 & $\begin{array}{l}\text { Beige silk sleeveless dress with } \\
\text { scoop neck and green threaded } \\
\text { embroidery, pleated knee length } \\
\text { skirt c. } 1930\end{array}$ & \begin{tabular}{|l|}
1985.2 .3 \\
KHW66 \\
Box \#4
\end{tabular} & $\begin{array}{l}\text { Day dress from period in } \\
\text { very good condition }\end{array}$ & Dorothy S. \\
\hline 39 & $\begin{array}{l}\text { White organdie wedding gown with } \\
\text { fitted bodice, puffed sleeves and } \\
\text { long skirt } \\
\text { Wedding of Naomi (Mayme) } \\
\text { Holland of Edmonton to Clifford } \\
\text { James of Edmonton July 1, } 1934\end{array}$ & $\begin{array}{l}1999.2 .002 \\
\text { KHW66 } \\
\text { Box \#106 }\end{array}$ & $\begin{array}{l}\text { Photocopy of article from } \\
\text { unknown newspaper dated } \\
\text { July 1, } 1939 \text { "Naomi Holland } \\
\text { is bride of early July" }\end{array}$ & Sandra G. \\
\hline 40 & $\begin{array}{l}\text { Black velvet coat with extended } \\
\text { collar dropping over to cap } \\
\text { shoulders, front button closure. } \\
\text { Cream silk lining and self buttons } \\
\text { c.1930s }\end{array}$ & $\begin{array}{l}\text { 1996.1.12 } \\
\text { KHW66 } \\
\text { Rack \#1 }\end{array}$ & $\begin{array}{l}\text { Beautiful construction, } \\
\text { princess seaming, 1940s } \\
\text { details }\end{array}$ & Beverly B. \\
\hline
\end{tabular}


Re-Collection of the Ryerson Fashion Research Collection

Table 7: Selected Artifacts 1940-1949

\begin{tabular}{|c|c|c|c|c|}
\hline & Description (including Label) & $\begin{array}{l}\text { Accession } \\
\text { Number/Location }\end{array}$ & Reason for Selection & Donor \\
\hline 41 & $\begin{array}{l}\text { Pale green evening dress with box } \\
\text { neckline and floral beading on } \\
\text { sleeves and bodice } \\
\text { No label c. } 1937-40\end{array}$ & $\begin{array}{l}1981.7 .3 \\
\text { KHW66 } \\
\text { Box } 2\end{array}$ & From first year of donations & $\begin{array}{l}\text { Kathy } \\
\text { Cleaver }\end{array}$ \\
\hline 42 & $\begin{array}{l}\text { Black crepe evening gown with V- } \\
\text { neck and short puffed sleeves with } \\
\text { bow, peblum waist with back ties } \\
\text { Label: Raphael Mack Hamilton } \\
\text { c. } 1945 \\
\text { Notation on tag reads worn by } \\
\text { donor's sister Librarian Teacher's } \\
\text { College Toronto }\end{array}$ & $\begin{array}{l}\text { FIC } \\
\text { KHW66C } \\
\text { Rack 1 }\end{array}$ & $\begin{array}{l}\text { Period silhouette (small hole } \\
\text { in neckline but otherwise in } \\
\text { good condition) }\end{array}$ & Miss Judith \\
\hline 43 & $\begin{array}{l}\text { Gray wool double breasted jacket } \\
\text { with wide lapels and Calf length } \\
\text { skirt with kick pleats } \\
\text { White cotton short-sleeve blouse } \\
\text { Label: Joan Rigby Toronto c. } \\
\text { 1940s }\end{array}$ & $\begin{array}{l}\text { FIC } \\
\text { KHW66C } \\
\text { Rack 1 }\end{array}$ & Very fine detailing on jacket & Unknown \\
\hline 44 & $\begin{array}{l}\text { Navy blue wool coat with deep rose } \\
\text { pink silk lining, no closures } \\
\text { Valentina } \text { c. } 1945\end{array}$ & $\begin{array}{l}\text { 1999.4.03 } \\
\text { KHW66C } \\
\text { Rack1 }\end{array}$ & Rare USA designer label & Donna C. \\
\hline 45 & $\begin{array}{l}\text { Burgundy Velvet Jacket with raglan } \\
\text { sleeves, unusual pocket detail and } \\
\text { draping } \\
\text { Label: CHRISTIAN DIOR - New } \\
\text { York } \\
\text { Imported Irving Detroit } \\
\text { c. } 1948-1949\end{array}$ & $\begin{array}{l}2000.02 .053 \\
\text { KHW66 } \\
\text { Box } 101\end{array}$ & $\begin{array}{l}\text { Rare and beautiful example } \\
\text { of couture }\end{array}$ & Anonymous \\
\hline 46 & $\begin{array}{l}\text { Black crepe dress with short } \\
\text { sleeves, peblum waist detail to back } \\
\text { tie, floral sequin spray across left } \\
\text { shoulder } \\
\text { c. } 1948\end{array}$ & $\begin{array}{l}1993.4 .10 \\
\text { Library } \\
\text { Hanging } \\
\text { Cupboard } 2\end{array}$ & $\begin{array}{l}\text { Embellishment } \\
\text { Period silhouette }\end{array}$ & $\begin{array}{l}\text { Donna Jean } \\
\text { M. }\end{array}$ \\
\hline
\end{tabular}


Re-Collection of the Ryerson Fashion Research Collection Table 8: Selected Artifacts 1950-1959

\begin{tabular}{|c|c|c|c|c|}
\hline & Description (including Label) & $\begin{array}{l}\text { Accession } \\
\text { Number/Location }\end{array}$ & Reason for Selection & Donor \\
\hline 47 & $\begin{array}{l}\text { Brown boucle wool jacket with } 3 / 4 \\
\text { sleeves; Sleeve cut as one piece } \\
\text { with bodice; Closes with } 3 \text { large } \\
\text { buttons; Front faux pockets } \\
\text { (Likely was once a matching skirt) } \\
\text { Label: CHRISTIAN DIOR for Holt } \\
\text { Renfrew } \\
\text { c. } 1950 \text { s }\end{array}$ & $\begin{array}{l}\text { FIC } \\
\text { KHW66C } \\
\text { Rack \#1 }\end{array}$ & $\begin{array}{l}\text { Couture } \\
\text { Canadian retailer }\end{array}$ & Unknown \\
\hline 48 & $\begin{array}{l}\text { Pale green satin strapless ballgown, } \\
\text { boned bodice and crinolined skirt } \\
\text { with train } \\
\text { Floral spray at bustline } \\
\text { PIERRE BALMAIN Marie } \\
\text { Antoinette } \\
\text { c. } 1957\end{array}$ & $\begin{array}{l}1989.6 .5 \\
\text { KHW66 } \\
\text { Box \#10 }\end{array}$ & $\begin{array}{l}\text { Rare and beautiful example } \\
\text { of couture } \\
\text { Gown is numbered }\end{array}$ & $\begin{array}{l}\text { Sommer } \\
\text { Rotenberg }\end{array}$ \\
\hline 49 & $\begin{array}{l}\text { Sleeveless black wool evening } \\
\text { gown and matching bolero jacket } \\
\text { Fitted long gown with tulip hem } \\
\text { and side button detail. Neckline has } \\
\text { beading and threaded velvet ribbon } \\
\text { c. } 1959 \\
\text { Label: BALENCIAGA } \\
\text { 10 Avenue George } \\
\text { Made in France }\end{array}$ & $\begin{array}{l}1997.4 .50 \\
\text { KHW66C } \\
\text { Rack \#1 }\end{array}$ & $\begin{array}{l}\text { Very fine workmanship and } \\
\text { cut } \\
\text { Bolero jacket is cut on bias } \\
\text { in circular shape }\end{array}$ & Barbara M. \\
\hline 50 & $\begin{array}{l}\text { Citron yellow sleeveless dress with } \\
\text { gathered waist and bow } \\
\text { Cropped jacket lined in turquoise } \\
\text { satin with front bow closure } \\
\text { Label: Bill Blass for Maurice } \\
\text { Rentner } \\
\text { c.1955-1963 }\end{array}$ & $\begin{array}{l}\text { 1986.1.1 A+B } \\
\text { KHW66C } \\
\text { Rack \#2 }\end{array}$ & $\begin{array}{l}\text { Label } \\
\text { Very fine finishing } \\
\text { Petersham belt on dress }\end{array}$ & Barbara M. \\
\hline 51 & $\begin{array}{l}\text { Gray day wool dress with diagonal } \\
\text { bust darts and flared skirt } \\
\text { Dress closes at back with zipper and } \\
\text { overlayed self button detail } \\
\text { Lined in white silk } \\
\text { Label: Jacques Heim Paris } \\
\text { Rio de Janeiro } \\
\text { Cannes Bairritz Deauville } \\
\text { c. 1958-1962 }\end{array}$ & $\begin{array}{l}1997.4 .28 \\
\text { KHW66C } \\
\text { Rack \#2 }\end{array}$ & $\begin{array}{l}\text { Designer Label } \\
\text { (Likely missing jacket) }\end{array}$ & Barbara M. \\
\hline
\end{tabular}


Re-Collection of the Ryerson Fashion Research Collection Table 9: Selected Artifacts 1950-1959 continued

\begin{tabular}{|c|c|c|c|c|}
\hline & Description (including Label) & $\begin{array}{l}\text { Accession } \\
\text { Number/Location }\end{array}$ & Reason for Selection & Donor \\
\hline 52 & $\begin{array}{l}\text { Pink satin strapless dress with full skirt } \\
\text { (likely worn over crinoline) and net } \\
\text { lining } \\
\text { Bodice is boned and lined } \\
\text { Skirt is draped into petal shape } \\
\text { Large front bow on left hip c. 1950s } \\
\text { Label: Made in Italy for Creeds }\end{array}$ & $\begin{array}{l}\text { FIC } \\
\text { KHW66C } \\
\text { Rack 1 }\end{array}$ & $\begin{array}{l}\text { Toronto label } \\
\text { Dior like dress shows } \\
\text { influence of Paris on fashion } \\
\text { of the period }\end{array}$ & Unknown \\
\hline 53 & $\begin{array}{l}\text { Cream silk short cap sleeve wedding } \\
\text { dress with drop waist pleated panel } \\
\text { skirt, } 37 \text { decorative buttons, shawl } \\
\text { collar, lined with sateen } \\
\text { Label: LISA Gowns, Toronto }\end{array}$ & $\begin{array}{l}\text { 2005.02.001 } \\
\text { KHW66C } \\
\text { Rack 1 }\end{array}$ & $\begin{array}{l}\text { Provenance as Mary } \\
\text { Suddon's wedding dress } \\
\text { Donation included photos }\end{array}$ & $\begin{array}{l}\text { Mary } \\
\text { Suddon }\end{array}$ \\
\hline 54 & $\begin{array}{l}\text { Brown net turban style hat with black } \\
\text { beads } \\
\text { Label: Miss Dior Created by Christian } \\
\text { Dior }\end{array}$ & $\begin{array}{l}\text { 1991.5.005 } \\
\text { KHW66 }\end{array}$ & Designer Label & Margaret $\mathrm{P}$ \\
\hline 55 & $\begin{array}{l}\text { Women's pink corded silk with black } \\
\text { feather trim } \\
\text { Label: } \text { Lily Hats, Miami }\end{array}$ & $\begin{array}{l}\text { 1991.5.002 } \\
\text { KHW66 }\end{array}$ & $\begin{array}{l}\text { Designer Label } \\
\text { Aesthetics of hat }\end{array}$ & Margaret $P$ \\
\hline
\end{tabular}


Re-Collection of the Ryerson Fashion Research Collection Table 10: Selected Artifacts 1960-1969

\begin{tabular}{|c|c|c|c|c|}
\hline & Description (including Label) & $\begin{array}{l}\text { Accession } \\
\text { Number/Location }\end{array}$ & Reason for Selection & Donor \\
\hline 56 & $\begin{array}{l}\text { Pink Boucle two-piece day suit } \\
\text { Box cut jacket with } 3 / 4 \text { two-piece } \\
\text { sleeves, front flap pockets, round collar } \\
\text { and bow closure with snap, lined in } \\
\text { pink silk; Knee length panel skirt with } \\
\text { slight gathers at waist, lined in pink } \\
\text { silk } \\
\text { Label: SIMPSONS Original design by } \\
\text { PIERRE CARDIN c. } 1963-1965\end{array}$ & $\begin{array}{l}2012.01 .008 \mathrm{~A}+\mathrm{B} \\
\text { KHW66C } \\
\text { Rack \#2 }\end{array}$ & $\begin{array}{l}\text { Designer label } \\
\text { Canadian retailer }\end{array}$ & Neil W. \\
\hline 57 & $\begin{array}{l}\text { Black linen sleeveless sack day dress } \\
\text { with double buttons } \\
\text { Hem weighted with metal disks } \\
\text { Label: Givenchy Paris } \\
\text { Made in France }\end{array}$ & $\begin{array}{l}1997.4 .52 \\
\text { KHW66C } \\
\text { Rack \#2 }\end{array}$ & Couture, day dress & Barbara M. \\
\hline 58 & $\begin{array}{l}\text { Yellow sleeveless silk linen summer } \\
\text { dress with button detail at waist } \\
\text { Pockets and belt } \\
\text { Label: CHRISTIAN DIOR } \\
\text { ORIGINAL in Canada for Holt } \\
\text { Renfrew c. } 1960-65\end{array}$ & $\begin{array}{l}\text { 1997.4.1A } \\
\text { KHW66C } \\
\text { Rack \#2 }\end{array}$ & $\begin{array}{l}\text { Couture label } \\
\text { Canadian retailer }\end{array}$ & Barbara M. \\
\hline 59 & $\begin{array}{l}\text { Black linen drop waist day dress with } \\
\text { collar and deep V back } \\
\text { Hem is weighted with chain } \\
\text { Label: GIVENCHY PARIS } \\
\text { Made in France } \\
\text { c.1966-70 }\end{array}$ & $\begin{array}{l}1997.4 .26 \\
\text { KHW66C } \\
\text { Rack \#2 }\end{array}$ & $\begin{array}{l}\text { Designer label } \\
\text { Weighted hem is very } \\
\text { unusual }\end{array}$ & Barbara M. \\
\hline 60 & $\begin{array}{l}\text { Red wool crepe strapless floor length } \\
\text { dress. Centre front pleat from Empire } \\
\text { waistline, overwrap detail on boned } \\
\text { bodice } \\
\text { Label: VALENTINO } \\
\text { Spring/Summer 1965 Collection }\end{array}$ & $\begin{array}{l}\text { 1997.4.009 } \\
\text { Library Flat west }\end{array}$ & $\begin{array}{l}\text { Designer label } \\
\text { Valentino red } \\
\text { Photocopy of article } \\
\text { illustrating dress in file }\end{array}$ & Barbara M. \\
\hline 61 & $\begin{array}{l}\text { Viridian green wool day dress with } \\
\text { cowl neck, raglan sleeves and front } \\
\text { pocket detail, top stitching Size 12, } \\
\text { c.1966-70 } \\
\text { Label: JEAN PATOU PARIS } \\
\text { Made in France for Holt Renfrew }\end{array}$ & $\begin{array}{l}\text { 1997.4.20 } \\
\text { KHW66C } \\
\text { Rack \#2 }\end{array}$ & $\begin{array}{l}\text { Designer label (no longer } \\
\text { exists) } \\
\text { Very heavy } \\
\text { Should be stored flat } \\
\text { Lining showing stress }\end{array}$ & Barbara M. \\
\hline 62 & $\begin{array}{l}\text { Pink raw silk cowl neck sleeveless } \\
\text { evening gown with matching bolero } \\
\text { jacket embellished with black beads } \\
\text { Label: Nina Ricci Paris }\end{array}$ & $\begin{array}{l}1997.4 .3 \\
\text { KHW66C } \\
\text { Rack \#2 }\end{array}$ & Designer label & Barbara M. \\
\hline
\end{tabular}


Re-Collection of the Ryerson Fashion Research Collection Table 11: Selected Artifacts 1960-1969 continued

\begin{tabular}{|c|c|c|c|c|}
\hline & Description (including Label) & $\begin{array}{l}\text { Accession } \\
\text { Number/Location }\end{array}$ & Reason for Selection & Donor \\
\hline 63 & $\begin{array}{l}\text { Cream chiffon sleeveless Empire waist } \\
\text { floor length dress with metallic gold } \\
\text { applique bodice, c. } 1966 \\
\text { Label: DAVID E. REA LIMITED } \\
\text { Toronto, Canada }\end{array}$ & $\begin{array}{l}1982.5 .1 \\
\text { KHW66C } \\
\text { Rack \#1 }\end{array}$ & $\begin{array}{l}\text { Canadian designer (with } \\
\text { long history) } \\
\text { Classic } 1960 \text { s styling }\end{array}$ & Patricia I. \\
\hline 64 & 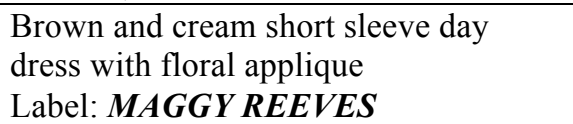 & $\begin{array}{l}\text { 1998.6.20 } \\
\text { Library } \\
\text { Hanging }\end{array}$ & Canadian designer & Unknown \\
\hline 65 & $\begin{array}{l}\text { Pink paisley long-sleeved jersey knit } \\
\text { midi-dress with quilted skirt and self } \\
\text { belt, c. 1965-68 } \\
\text { Label: SIMPSONS THE ROOM }\end{array}$ & $\begin{array}{l}1989.5 .86 \\
\text { KHW66C } \\
\text { Rack \#2 }\end{array}$ & $\begin{array}{l}\text { Canadian retailer } \\
\text { Example of } 1970 \text { s look }\end{array}$ & Karen M. \\
\hline 66 & $\begin{array}{l}\text { Yellow Boucle Wool Belted Coat, } \\
\text { slightly gathered at waist } \\
\text { Label: Christian Dior for Holt } \\
\text { Renfrew }\end{array}$ & $\begin{array}{l}1997.4 .44 \\
\text { KHW66C } \\
\text { Rack \#2 }\end{array}$ & $\begin{array}{l}\text { Designer label } \\
\text { Toronto retailer }\end{array}$ & Barbara M. \\
\hline 67 & $\begin{array}{l}\text { Green velvet Empire style Juliet dress } \\
\text { with pink satin puffed sleeves with } \\
\text { pearls } \\
\text { Label: Designed by Everett Staples for } \\
\text { Jean Pierce Toronto }\end{array}$ & $\begin{array}{l}\text { FIC } \\
\text { KHW66C } \\
\text { Rack \#1 }\end{array}$ & $\begin{array}{l}\text { Toronto designer and retailer } \\
\text { Romantic styling }\end{array}$ & $\begin{array}{l}\text { Unknown } \\
\text { (Miss Taylor } \\
\text { written on } \\
\text { label) }\end{array}$ \\
\hline 68 & $\begin{array}{l}\text { Orange Wool Sleeveless Dress with } \\
\text { front panel and buttoned side closures, } \\
\text { back zipper and back belt } \\
\text { Label: Modèle Guy Laroche Paris } \\
\text { Diffusé par maria carine Made in } \\
\text { France }\end{array}$ & $\begin{array}{l}1986.1 .21 \\
\text { KHW66C } \\
\text { Rack \#2 }\end{array}$ & Toronto retailer & Barbara M. \\
\hline 69 & $\begin{array}{l}\text { Cream wool whipcord sleeveless } \\
\text { Princess knee-length dress with cowl } \\
\text { collar lined in cream silk blend, centre } \\
\text { back zipper } \\
\text { Matching A-lined knee length coat } \\
\text { with collar, 3/4 sleeves, } 2 \text { front bows, } \\
\text { snap closures, decorative 3" band belt } \\
\text { to back Label: Robert K. Irwin }\end{array}$ & $\begin{array}{l}\text { 1992.1.9 A+B } \\
\text { KHW66C } \\
\text { Rack \#2 }\end{array}$ & $\begin{array}{l}\text { Designer Label } \\
\text { Seaming on dress and coat is } \\
\text { unusual }\end{array}$ & Anne P \\
\hline 70 & $\begin{array}{l}\text { Peach coloured wool suit, cropped } \\
\text { bolero type jacket with kimono style } \\
\text { sleeves lined in floral silk, closes with } \\
\text { snaps and one large woven button; A- } \\
\text { line calf length skirt without waistband, } \\
\text { lined in peach silk } \\
\text { Label: PIERRE CARDIN Made in } \\
\text { France } \\
\text { Holt Renfrew \& Co. Ltd. }\end{array}$ & $\begin{array}{l}\text { 1997.4.1.A+B } \\
\text { KHW66C } \\
\text { Rack \#2 }\end{array}$ & $\begin{array}{l}\text { Couture } \\
\text { Canadian retailer } \\
\text { Lining on jacket is very } \\
\text { pretty } \\
\text { Unusual sleeve }\end{array}$ & Barbara M. \\
\hline
\end{tabular}


Re-Collection of the Ryerson Fashion Research Collection

Table 12: Selected Artifacts 1970-1979

\begin{tabular}{|c|c|c|c|c|}
\hline & Description (including Label) & $\begin{array}{l}\text { Accession } \\
\text { Number/Location }\end{array}$ & Reason for Selection & Donor \\
\hline 71 & $\begin{array}{l}\text { Red and brown silk print dress with } \\
\text { diagonal waist detailing and back } \\
\text { panel, handkerchief hem c. } 1970 \mathrm{~s} \\
\text { Label: Pierre Cardin Paris } \\
\text { Made in France Holt Renfrew }\end{array}$ & $\begin{array}{l}1997.4 .3 \\
\text { KHW66C } \\
\text { Rack \#1 }\end{array}$ & $\begin{array}{l}\text { Designer Label } \\
\text { Canadian Retailer }\end{array}$ & Barbara M. \\
\hline 72 & $\begin{array}{l}\text { Slate grey/blue wool jumpsuit with } \\
\text { long sleeves and gathered cuffs, } \\
\text { bodice placket is gathered, front } \\
\text { buttons and zipper closure for pants, } \\
\text { size } 40 \\
\text { Label: Saint Laurent Rives Gauche } \\
\text { Made in France }\end{array}$ & $\begin{array}{l}1997.4 .39 \\
\text { KHW66C } \\
\text { Rack \#1 }\end{array}$ & $\begin{array}{l}\text { Jumpsuit } \\
\text { Designer ready to wear }\end{array}$ & Barbara M. \\
\hline 73 & $\begin{array}{l}\text { Burgundy velour tunic dress with } \\
\text { long sleeves and matching detachable } \\
\text { hood size 9/10 } \\
\text { Label: MARILYN BROOKS } \\
\text { c.1970s }\end{array}$ & $\begin{array}{l}\text { 1998.1.2 A+B } \\
\text { KHW66C } \\
\text { Rack \#1 }\end{array}$ & $\begin{array}{l}\text { Canadian designer } \\
\text { Period silhouette }\end{array}$ & Anne S. \\
\hline 74 & $\begin{array}{l}\text { CN Tower jumpsuit uniform rust } \\
\text { orange and gray printed cotton } \\
\text { Matching necktie in rust } \\
\text { Label: Career Tex Career Wear by } \\
\text { Sainthill Levine } \\
\text { c. } 1976 \text { or after }\end{array}$ & $\begin{array}{l}\text { FIC } \\
\text { Library } \\
\text { Hanging }\end{array}$ & $\begin{array}{l}\text { Canadian designer } \\
\text { History of Toronto with CN } \\
\text { Tower } \\
\text { Functional apparel }\end{array}$ & Unknown \\
\hline 75 & $\begin{array}{l}\text { Pink silk jersey dress with deep } \\
\text { collar embellished with pink, cream, } \\
\text { blue and purple sequins in floral } \\
\text { pattern, long sleeves with tie closures } \\
\text { Pleated skirt Maggy Reeves } \\
\text { Label: } \\
\text { c.1970s }\end{array}$ & $\begin{array}{l}\text { FIC } \\
\text { KHW66 } \\
\text { Rack \#2 }\end{array}$ & $\begin{array}{l}\text { Canadian label } \\
\text { Embellished collar }\end{array}$ & Unknown \\
\hline 76 & $\begin{array}{l}\text { Brown snake print silk long dress } \\
\text { with belt and bubble hem } \\
\text { Label: GIVENCHY MADE IN } \\
\text { PARIS Numbered 527 } \\
\text { c.1970s }\end{array}$ & $\begin{array}{l}\text { 1989.1.1 } \\
\text { KHW66 } \\
\text { Rack \#1 }\end{array}$ & Couture design/numbered & $\begin{array}{l}\text { Sommer } \\
\text { Rotenberg }\end{array}$ \\
\hline 77 & $\begin{array}{l}\text { Black and cream polka dot silk dress } \\
\text { with draped black skirt and deep V } \\
\text { front, invisible back zipper } \\
\text { Black belt lined with vinyl } \\
\text { Label: OSCAR DE LA RENTA } \\
\text { Made in the USA }\end{array}$ & $\begin{array}{l}2006.04 .93 \\
\text { KHW66 } \\
\text { Rack \#2 }\end{array}$ & Designer label & $\begin{array}{l}\text { Estate of } \\
\text { Mary Ryrie }\end{array}$ \\
\hline
\end{tabular}


Re-Collection of the Ryerson Fashion Research Collection Table 13: Selected Artifacts 1980-1989

\begin{tabular}{|c|c|c|c|c|}
\hline & Description (including Label) & $\begin{array}{l}\text { Accession } \\
\text { Number/Location }\end{array}$ & Reason for Selection & Donor \\
\hline 78 & $\begin{array}{l}\text { Black velvet knee length cocktail } \\
\text { dress with long sleeves, shoulder } \\
\text { pads c. } 1980 \text { s } \\
\text { BALENCIAGA}\end{array}$ & $\begin{array}{l}1987.4 .51 \\
\text { KHW66 } \\
\text { Box \#3 }\end{array}$ & $\begin{array}{l}\text { Designer ready to wear } \\
\text { Evolution of design label }\end{array}$ & Karen M. \\
\hline 79 & $\begin{array}{l}\text { White pleated silk cropped top with } \\
\text { matching skirt and belt wrapped in } \\
\text { gold trim } \\
\text { Top closes with back zipper } \\
\text { Skirt has side zipper, c. } 1985-89 \\
\text { Label: MARY McFADDEN Couture } \\
\text { Saks Fifth Avenue }\end{array}$ & $\begin{array}{l}2007.02 .01 \mathrm{~A}+\mathrm{B} \\
\text { KHW66C } \\
\text { Rack \#1 }\end{array}$ & $\begin{array}{l}\text { Textile } \\
\text { Designer label }\end{array}$ & $\begin{array}{l}\text { Tammy Y. } \\
\text { Letter from } \\
\text { donor on file }\end{array}$ \\
\hline 80 & $\begin{array}{l}\text { Gold lame Edwardian style top with } \\
\text { puffed sleeves and ruffles } \\
\text { Matching gold lame long gathered } \\
\text { skirt, c. } 1980 \\
\text { Label: Pat McDonagh } \\
\text { Made in Canada }\end{array}$ & $\begin{array}{l}2000.4 .002 \\
\text { KHW66C } \\
\text { Rack \#1 }\end{array}$ & $\begin{array}{l}\text { Canadian designer label } \\
\text { Link to Edwardian styling }\end{array}$ & Alice C. \\
\hline 81 & $\begin{array}{l}\text { Green leather hand-painted shoes } \\
\text { Thierry Mugler label, c. } 1980\end{array}$ & $\begin{array}{l}\text { 1994.1.30 } \\
\text { Library }\end{array}$ & Hand-painted shoes & Karen M. \\
\hline 82 & $\begin{array}{l}\text { Black jersey dress with dropped } \\
\text { shoulder with shoulder pads, long } \\
\text { inset sleeves gathered to a cuff, white } \\
\text { satin collar, godet skirt } \\
\text { Label: Jean Muir, Creeds (pre-1990) }\end{array}$ & $\begin{array}{l}\text { 2009.01.395 } \\
\text { KHW66C } \\
\text { Rack \#3 }\end{array}$ & $\begin{array}{l}\text { Designer Label } \\
\text { Canadian retailer label }\end{array}$ & $\begin{array}{l}\text { Kathleen } \\
\text { Kubas }\end{array}$ \\
\hline 83 & $\begin{array}{l}\text { Burgundy textured knit jersey } \\
\text { pullover dress with turtleneck collar } \\
\text { and long gathered sleeves with } \\
\text { matching overcoat with elbow length } \\
\text { wide sleeves, self-tie } \\
\text { Label: Missoni Creeds Toronto } \\
\text { (pre-1990) }\end{array}$ & $\begin{array}{l}\text { 2009.01.684 A+B } \\
\text { KHW66C } \\
\text { Rack \#3 }\end{array}$ & $\begin{array}{l}\text { Italian Designer Label } \\
\text { Non-traditional piece for } \\
\text { label } \\
\text { Beautiful texture of fabric } \\
\text { Avant-garde styling }\end{array}$ & $\begin{array}{l}\text { Kathleen } \\
\text { Kubas }\end{array}$ \\
\hline 84 & $\begin{array}{l}\text { Gray wool long sleeved angle-length } \\
\text { dress with Nehru collar and } \\
\text { asymmetrical bodice wrap } \\
\text { Sleeves are ruched } \\
\text { Label: Claude Montana c.1980s }\end{array}$ & $\begin{array}{l}2009.01 .260 \\
\text { KHW66C } \\
\text { Rack \#3 }\end{array}$ & $\begin{array}{l}\text { Construction } \\
\text { Designer label }\end{array}$ & $\begin{array}{l}\text { Kathleen } \\
\text { Kubas }\end{array}$ \\
\hline 85 & $\begin{array}{l}\text { Brown wool vest with tab sides and } \\
\text { blazer-like collar, } 2 \text { metal snap } \\
\text { closures; Matching midi-length wool } \\
\text { skirt with paper-bag waist and } \\
\text { unfinished hem, belt with metal snap } \\
\text { closure detail } \\
\text { Label: Linda Lundstrom }\end{array}$ & $\begin{array}{l}2009.01 .391 \mathrm{~A}+\mathrm{B} \\
\text { KHW66C } \\
\text { Rack \#3 }\end{array}$ & Canadian design label & $\begin{array}{l}\text { Kathleen } \\
\text { Kubas }\end{array}$ \\
\hline
\end{tabular}


Re-Collection of the Ryerson Fashion Research Collection Table 14: Selected Artifacts 1980-1989 continued.

\begin{tabular}{|c|l|l|l|l|}
\hline 86 & $\begin{array}{l}\text { Gray wool wrap front dress with } \\
\text { dolman sleeves, mid-calf length skirt } \\
\text { with front slit, hidden side pockets } \\
\text { Label: Donna Karan }\end{array}$ & $\begin{array}{l}2009.01 .219 \\
\text { KHW66C } \\
\text { Rack \#3 }\end{array}$ & $\begin{array}{l}\text { USA designer label } \\
\text { Example of working } \\
\text { women's "effortless } \\
\text { dressing" }\end{array}$ & $\begin{array}{l}\text { Kathleen } \\
\text { Kubas }\end{array}$ \\
\hline 87 & $\begin{array}{l}\text { Blue wool box-cut jacket with inset } \\
\text { sleeves, decorative beaded over-panel } \\
\text { lined in red silk, attached at collar } \\
\text { Black velvet Mandarin collar } \\
\text { Matching panel skirt with kick pleat } \\
\text { Label: Chloe H.R. Boutique }\end{array}$ & $\begin{array}{l}2009.01 .676 \text { A+B } \\
\text { KHW66C } \\
\text { Rack \#3 }\end{array}$ & $\begin{array}{l}\text { European designer label } \\
\text { Beaded embellishment }\end{array}$ & $\begin{array}{l}\text { Kathleen } \\
\text { Kubas }\end{array}$ \\
\end{tabular}


Re-Collection of the Ryerson Fashion Research Collection Table 15: Selected Artifacts Post-1990

\begin{tabular}{|l|l|l|l|l|}
\hline & Description (including Label) & $\begin{array}{l}\text { Accession } \\
\text { Number/Location }\end{array}$ & Reason for Selection & Donor \\
\hline 88 & $\begin{array}{l}\text { Women's tailcoat } \\
\text { Label: } \text { Rei Kawakubo Commes de } \\
\text { Garcons }\end{array}$ & $\begin{array}{l}2006.01 .23 \\
\text { KHW66C } \\
\text { Rack \#1 }\end{array}$ & $\begin{array}{l}\text { Designer - contemporary } \\
\text { interpretation of men's } \\
\text { tails }\end{array}$ & Karen M. \\
\hline 89 & $\begin{array}{l}\text { Gray sequined evening dress with } \\
\text { plunging neckline, narrow straps and } \\
\text { train }\end{array}$ & $\begin{array}{l}\text { FIC } \\
\text { KHW66C } \\
\text { Lack \#1 } \\
\text { dress was designed for opening of } \\
\text { Crystal by Pat McDonagh c. 2007 }\end{array}$ & $\begin{array}{l}\text { Provenance as a dress } \\
\text { worn to the Crystal } \\
\text { opening May 2007 }\end{array}$ & Unknown \\
\hline 90 & $\begin{array}{l}\text { Felted wool dress in multi-coloured } \\
\text { print } \\
\text { Label: } \text { Issey } \text { Miyake }\end{array}$ & $\begin{array}{l}2009.01 .251 \\
\text { KHW66C } \\
\text { Rack \#3 }\end{array}$ & $\begin{array}{l}\text { Textile is unusual } \\
\text { Designer label }\end{array}$ & $\begin{array}{l}\text { Kathleen } \\
\text { Kubas }\end{array}$ \\
\hline 91 & $\begin{array}{l}\text { Quilted silk, wool, and tweed jacket, } \\
\text { kimono style } \\
\text { Label: } \text { Kenzo }\end{array}$ & $\begin{array}{l}2009.01 .686 \\
\text { KHW66C } \\
\text { Rack \#3 }\end{array}$ & $\begin{array}{l}\text { Designer label } \\
\text { Beautiful textile }\end{array}$ & $\begin{array}{l}\text { Kathleen } \\
\text { Kubas }\end{array}$ \\
\hline 92 & $\begin{array}{l}\text { Black and white pleated kimono style } \\
\text { jacket/top with handkerchief hem } \\
\text { Label: } \text { Issey } \text { Miyake }\end{array}$ & $\begin{array}{l}2009.01 .282 \\
\text { KHW66C } \\
\text { Rack \#3 }\end{array}$ & $\begin{array}{l}\text { Designer label } \\
\text { Innovative styling }\end{array}$ & $\begin{array}{l}\text { Kathleen } \\
\text { Kubas }\end{array}$ \\
\hline 93 & $\begin{array}{l}\text { Gray suede long wrap skirt and } \\
\text { matching fur and floral painted } \\
\text { leather jacket with tie belt } \\
\text { Label: } \text { Dolce \& Gabbana }\end{array}$ & $\begin{array}{l}2009.01 .226 \text { ABC } \\
\text { KHW66C } \\
\text { Rack \#3 }\end{array}$ & $\begin{array}{l}\text { Designer label } \\
\text { Painting of leather lining }\end{array}$ & $\begin{array}{l}\text { Kathleen } \\
\text { Kubas }\end{array}$ \\
\hline 94 & $\begin{array}{l}\text { Wooly mammoth-like sweater coat } \\
\text { ensemble with fine wool purple } \\
\text { sweater dress } \\
\text { Label: } \text { Krizia }\end{array}$ & $\begin{array}{l}2009.01 .266 \mathrm{~A}+\mathrm{B} \\
\text { KHW66C } \\
\text { Rack \#3 }\end{array}$ & $\begin{array}{l}\text { European designer label } \\
\text { Donor's affinity for colour } \\
\text { purple }\end{array}$ & $\begin{array}{l}\text { Kathleen } \\
\text { Kubas }\end{array}$ \\
\hline
\end{tabular}


Re-Collection of the Ryerson Fashion Research Collection Table 16: Selected Artifacts Post-1990 Hats

\begin{tabular}{|c|c|c|c|c|}
\hline & Description (including Label) & $\begin{array}{l}\text { Accession } \\
\text { Number/Location }\end{array}$ & Reason for Selection & Donor \\
\hline 95 & $\begin{array}{l}\text { Fuchsia pink hat with large brim and } \\
\text { fixed bow } \\
\text { Label: Philip Tracey }\end{array}$ & $\begin{array}{l}\text { 2009.01.444 } \\
\text { KHW66C }\end{array}$ & $\begin{array}{l}\text { Designer Label } \\
\text { Donor's affinity for colour } \\
\text { Multiple copies of similar } \\
\text { hat styles }\end{array}$ & $\begin{array}{l}\text { Kathleen } \\
\text { Kubas }\end{array}$ \\
\hline 96 & $\begin{array}{l}\text { Black Mad-hatter women's hat, silk } \\
\text { flowers and fur-like feathers } \\
\text { Label: Phillip Tracey }\end{array}$ & $\begin{array}{l}2009.01 .512 \\
\text { KHW66C }\end{array}$ & $\begin{array}{l}\text { Designer label } \\
\text { Menswear styling }\end{array}$ & $\begin{array}{l}\text { Kathleen } \\
\text { Kubas }\end{array}$ \\
\hline 97 & $\begin{array}{l}\text { Gray fedora felted wool hat with two } \\
\text { brown clipper feathers } \\
\text { Label: Phillip Tracey }\end{array}$ & $\begin{array}{l}\text { 2009.01.402 } \\
\text { KHW66C }\end{array}$ & $\begin{array}{l}\text { Designer label } \\
\text { Menswear styling } \\
\text { Affinity for gray }\end{array}$ & $\begin{array}{l}\text { Kathleen } \\
\text { Kubas }\end{array}$ \\
\hline 98 & $\begin{array}{l}\text { Beige raffia-like large-brimmed hat } \\
\text { with layered and draped raffia } \\
\text { Scattered black sequins } \\
\text { Label: Linda Campisano Millinery } \\
\text { Chicago } \\
\text { Business card in bottom of box } \\
900 \text { N. Michigan Avenue, Chicago } \\
\text { 312-337-1004 }\end{array}$ & $\begin{array}{l}\text { 2009.01.694 } \\
\text { KHW66C }\end{array}$ & $\begin{array}{l}\text { Avant-garde design } \\
\text { Beautiful original box }\end{array}$ & $\begin{array}{l}\text { Kathleen } \\
\text { Kubas }\end{array}$ \\
\hline 99 & $\begin{array}{l}\text { Women's black hat, styled like a top } \\
\text { hat with black feather } \\
\text { Label: Phillip Tracey }\end{array}$ & $\begin{array}{l}\text { 2009.01.695 } \\
\text { KHW66C }\end{array}$ & $\begin{array}{l}\text { Designer label } \\
\text { Menswear styling }\end{array}$ & $\begin{array}{l}\text { Kathleen } \\
\text { Kubas }\end{array}$ \\
\hline
\end{tabular}

Re-Collection of the Ryerson Fashion Research Collection Table 17: Selected Artifacts 2012

\begin{tabular}{|l|l|l|l|l|}
\hline & Description (including Label) & $\begin{array}{l}\text { Accession } \\
\text { Number/Location }\end{array}$ & Reason for Selection & Donor \\
\hline 100 & $\begin{array}{l}\text { Black menswear style jacket with } \\
\text { tails }\end{array}$ & $\begin{array}{l}2012.02 .002 \\
\text { F/W 2012 }\end{array}$ & Contemporary Canadian & Andrea \\
& SMYTHE & & $\begin{array}{l}\text { Lenczner \& } \\
\text { Christie } \\
\text { Smythe }\end{array}$ \\
\hline
\end{tabular}




\section{Bibliography}

Alberti, Samuel J. “Objects and the Museum.” Isis 96.4 (2005): 559-71. Print.

Amnedus, Cynthia. "Fashion Designers, Seamstresses, and Tailors." Berg Encyclopedia of World Dress and Fashion 3.2 (2010) Web Jan. 2013.

Banim, Maura, and Ali Guy. "Dis/continued Selves: Why do Women Keep Clothes they no Longer Wear?" Through the Wardrobe: Women's Relationships with their Clothes. Eds. Alison Guy, Maura Banim, and Eileen Green. New York: Berg, 2001. 203-219. Print.

Barthes, Roland. Camera Lucida: Reflections on Photography. 1st pbk. ed. New York: Hill and Wang, 1982, 1981. Print.

Batts, M. "Eaton's and its Catalogues: An Expression of Canadian Social History." Costume 7.1 (1973): 68-9. Print.

Baudot, François. "Fashion: The Twentieth Century.” New York: Rizzoli, 2007. Print.

Baudrillard, Jean. The System of Objects. Tran. James Benedict. New York: Verso, 1996. Print. 
Blinova, Vlada. "Re: University of Alberta Study Collection". Message to Author, 30 May 2012. Email.

Bolton, Andrew. "The Curatorial Process for Alexander McQueen: Savage Beauty”. Oral Presentation at Pratt Institute, New York City. September 18, 2012.

Boynton-Arthur, Linda. "Resources for Costume Collections in American Universities". Journal of Family and Consumer Sciences, (Fall 1997) 89(3), 57-60. Print.

Beaujot, Ariel. Victorian Fashion Accessories. London: Berg, 2012. Print.

Beecher, Mrs. H. W. "All Around the House; Or how to make Homes Happy." Robertson's Cheap Series 1881. Print.

Blum, Stella, ed. Victorian Fashions \& Costumes from Harper's Bazaar 1867-1898. New York: Dover Publications, 1974. Print.

Bourdieu, Pierre. Distinction: A Social Critique of the Judgment of Taste. Tran. Richard Nice. Cambridge, Mass.: Harvard University Press, 1984, 9th printing 1998. Print.

Brett, Katharine B. Modesty to Mod: Dress and Underdress in Canada 1780-1967. Toronto: University of Toronto Press, 1967. Print. 
---. Women's Costume in Ontario, 1867-1907. Ed. Royal Ontario Museum. Toronto: Royal Ontario Museum, University of Toronto, 1966. Print.

"Brooklyn Museum Guide to the Records of the Department of Costumes and Textiles 1911 2004.” Web. Oct. 2012

Campbell, Colin. "The Meaning of Objects and the Meaning of Actions: A Critical Note on the Sociology of Consumption and Theories of Clothing." Journal of Material Culture 1.1 (1996): 93-106. Print.

Carrara, Gillion. "The SAIC Fashion Resource Center". Costume Collections: A Collaborative Model for Museums. May 21-22, 2010, Brooklyn Museum, New York. Metropolitan Museum of Art, n.d., Web, Jan. 2013.

---, Personal Interview, SAIC, Chicago. 12 July 2012.

Carter, Joyce. "Mod Styles of 1867.” Globe Magazine December 31, 1966. Print.

---. "Will future keep Dressmakers in Stitches." Globe \& Mail Dec. 2, 1971. W14. Print.

Cawthorne, Nigel. The New Look: The Dior Revolution. London: Hamlyn, 1996. Print.

Cleaver, Kathy. Personal Interview, Toronto. 26 June 2012. 
---. Letter to Mrs. George Gooderham, October 14, 1981; Ryerson Fashion Research Collection Donations Binder 1981-1989. Print.

---. Letter from Lois T., undated [1983]; Ryerson Fashion Research Collection Donations Binder 1981-1989. Print.

---. Letter to Ruth D., September 28, 1987; Ryerson Fashion Research Collection Donations Binder 1981-1989. Print.

---. Letter from Barbara M., undated [1988]; Ryerson Fashion Research Collection Donations Binder 1981-1989. Print.

---. Letter from Betty T., August 15, 1989; Ryerson Fashion Research Collection Donations Binder 1981-1989. Print.

---. Letter from Anne P., April 24, 1992; Ryerson Fashion Research Collection Donations Binder 1990-1999. Print.

---. Letter from Dolores D., April 29, 1995; Ryerson Fashion Research Collection Donations Binder 1990-1999. Print.

---. Email to Ariella H., June 4, 2002; Ryerson Fashion Research Collection Donations Binder 2000-2009. Print. 
---. Letter from Isabell M., January 20, 2004; Ryerson Fashion Research Collection Donations Binder 2000-2009. Print.

Collard, Constance Eileen McCarthy. The Cut of Women's 19th Century Dress. Rev. and enl. ed. ed. Burlington, Ont.: Eileen Collard, 1980. Print.

---. Early Clothing in Southern Ontario. Burlington, Ont.: E. Collard, [1969]. Print.

_. "The Intimate Woman," Costume Society of Ontario Newsletter. Volume 9, Number 3. December 1979. Ed. Alan Suddon, 5-8. Print.

Cooper, Cynthia. "The Garment Industry and Retailing in Canada." Berg Encyclopedia of World Dress and Fashion 3.2 (2010) Web, Nov. 2011.

---. Personal Interview, Montreal. 5 April 2012.

Costume Society of America. "Overview and Resolution”. N.d.,Web, Oct. 2012.

Costume Society of Ontario Journal, Winter 1984-5, Volume 14, Number 2. Ed. Caroline Routh. Print.

Crane, Susan A., ed. Museums and Memory. Stanford: Stanford University Press, 2000. Print. 
Dant, Tim. Material Culture in the Social World. Philadelphia: Open University Press, 1999. Print.

De La Haye, Amy. "Introduction: Dress and Fashion in the Context of the Museum.” Berg Encyclopedia of World Dress and Fashion 10.5 (2010) Web.

De La Haye, Amy. A Family of Fashion: The Messels: Six Generations of Dress. Eds. Lou Taylor and Eleanor Thompson. London: Philip Wilson Publishers, 2005. Print.

De La Haye, Amy, and Judith Clark. "One Object: Multiple Interpretations.” Fashion Theory 12.2 (2008): 137-70. Print.

De Marly, Diana. The History of Haute Couture, 1850-1950. New York: Holmes and Meier, 1980. Print.

Drexel University Historic Costume Collection. Drexel University, n.d.,Web. June 2012.

Druesedow, Jean. “Re: Study Collections.” Message to Author. 9 May 2012. E-mail.

Dudley, Sandra H., ed. Museum Materialities: Objects, Engagements, Interpretations. New York: Routledge, 2010. Print. 
Dudley, Sandra, et al, eds. The Thing about Museums: Objects and Experience, Representation and Contestation. New York: Routledge, 2012. Print.

Edwards, Elizabeth. "Photographs as Objects of Memory." Material Memories: Design and Evocation. Eds. Marius Kwint, Christopher Breward, and Jeremy Aynstey. New York: Berg, 1999. 221-236. Print.

"Edwardian Dresses on Show at Ryerson". Toronto Star. September 30, 1989. N.p.. Print.

Entwistle, Joanne. The Fashioned Body: Fashion, Dress and Modern Social Theory. Malden, MA: Polity Press, 2000. Print.

Farley, Jennifer. Personal Interview: FIT Study Collection, New York. 26 July 2012.

Fashion: A Canadian Perspective. Ed. Alexandra Palmer. Toronto: University of Toronto Press, 2004. Print.

Fashion: A History from the 18th to the 20th Century. Eds. Akiko Fukai, Tamami Suoh. Los Angeles: Taschen, 2006. Print.

FIDM Museum \& Galleries. FIDM, n.d., Web, March 2012.

FIT Museum. FIT, n.d. Web, June 2012. 
Freeman, Barbara M. "Laced in and Let Down: Women's Fashion Features in the Toronto Daily Press, 1890-1900." Fashion: A Canadian Perspective. Ed. Alexandra Palmer. University of Toronto Press, 2004. 291-311. Print.

Frisa, Maria Luisa. “The Curator's Risk.” Fashion Theory 12.2 (2008): 171-80. Print.

"From Home Ec to High Tech: Ryerson University showcases the evolution of fashion education over six decades." Ryerson University Media Release. November 14, 2007. Web. Nov. 2012.

Fukai, Akiko, and Brian Moeran. "Dress and Fashion Museums.” Berg Encyclopedia of World Dress and Fashion 10.5 (2010) Web.

Fulsang, Deborah. "The Fashion of Writing, 1985-2000: Fashion-Themed Televisions Impact on the Canadian Fashion Press." Fashion: A Canadian Perspective. Ed. Alexandra Palmer. Toronto: University of Toronto Press, 2004. 315-338. Print.

Gernsheim, Alison. Victorian \& Edwardian Fashion: A Photographic Survey. New York: Dover Publications, 1981. Print. 
Glier Reeder, Jan. "An Overview of the Costume Documentation Project". Conference Proceeding Costume Collections: A Collaborative Model for Museums. May 21-22, 2010, Brooklyn Museum, New York. Metropolitan of Art Museum, n.d. Web, Jan. 2013.

Glier Reeder, Jan. High Style: Masterworks from the Brooklyn Museum Collection at the Metropolitan Museum of Art. New York: Yale University Press: 2010. Print.

The Golden Age of Couture: Paris and London 1947-57. Ed. Claire Wilcox. London: V\&A Publications, 2007. Print.

Gostick, Sheila. “A Stitch in Time: Gowns by Famed Yorkville Designer Sadly Go for a Song at Uppity Auction." NOW Magazine 24.10 (2005) Print.

---. "Style Stood Still 200 Years of Costume History Ranks as My Fashion Find of the Year." NOW Magazine 19.41 (2000) Print.

Granata, Francesca. "Fashion \& Memory." Fashion Projects: On Fashion and Memory, 3: 23. Print.

---. "Fashion Studies in-between: A Methodological Case Study and an Inquiry into the State of Fashion Studies." Fashion Theory: The Journal of Dress, Body \& Culture 16.1 (2012): 67-82. Print. 
Hastings, Nancy. “Exhibit features ‘60s gear.” Toronto Star 11 June 1987. n.p., Print.

Holford, Mary. "Select Additions to the ROM Textile and Costume Collections since 1974". Costume Society of Ontario Newsletter, Volume 9, Number 1, March 1979. Ed. Alan Suddon. 6. Print.

Interpreting Objects and Collections. Ed. Susan M. Pearce. New York: Routledge, 1994. Print.

International Council of Museums, Costume Committee. "Guidelines for Costume". ICOM, n.d. Web. Oct. 2012.

“Institute Fits Women for Fashion Industry”. Globe \& Mail. 5 January 1949. P10. Print.

“Celebrating Kathleen Lonergan Kubas Mary 12, 1938 - November 22, 2008”. Undated booklet. Print.

Kelcey, Barbara E. "Dress Reform in Nineteenth-Century Canada." Fashion: A Canadian Perspective. Ed. Alexandra Palmer. Toronto: University of Toronto Press, 2004. Print.

Kent State University Museum Gallery of Costume. Kent State University, n.d. Web. June 2012. 
Koda, Harold. "Collection Sharing: History of the Costume Institute." Costume Collections: A Collaborative Model for Museums. May 21-22, 2010, Oral Presentation at Brooklyn Museum, New York. Metropolitan Museum of Art, n.d. Web. Jan. 2013.

Kopytoff, Igor. "The Cultural Biography of Things: Commoditization as Process." The Social Life of Things: Commodities in Cultural Perspective. Ed. Arjun Appadurai. Cambridge: Cambridge University Press, 1986. 64-91. Print.

Jones, Kevin. “Re: FIDM Study Collection”. Message to Author. 27 August 2012. Email.

Langley Moore, Doris. The Woman in Fashion. New York: B.T. Batsford Ltd., 1949. Print.

Lawrence, Deirdre E. "Costume and Fashion Design as Seen Through the Brooklyn Museum Library Collection." Performing Arts Resources 27. (2010): 94-99. International Bibliography of Theatre \& Dance. Web. Oct. 2012

Lucas, Gavin. "Disposability and Dispossession in the Twentieth Century." Journal of Material Culture 5.4 (2002): 1-22. Print.

Marcketti, Sara. “Re: Iowa State University Study Collection”. Message to Author, 4 June 2012. Email.

Marcketti, Sara, et al. "University Historic Clothing Museums and Collections: Practices and Strategies." Clothing \& Textiles Research Journal 29.3 (2011): 248-62. Print. 
“Marilyn Brooks”. Canadian Encyclopedia. n.d. Web. Jan. 2013.

Material Memories. Eds. Marius Kwint, Christopher Breward, and Jeremy Aynsley. New York: Berg, 1999. Print.

McDowell, Colin. Directory of Twentieth Century Fashion. New York: Prentice Hall Press, 1987. Print.

Mendes, Valerie D. Lucile Ltd: London, Paris, New York and Chicago, 1890s-1930s. Eds. Amy De La Haye and Victoria \& Albert Museum. London: V\&A Publishing, 2009. Print.

Murphy, Deirdre. "Dialogues between Past and Present: Historic Garments as Source Material for Contemporary Fashion Design.” V\&A Online Journal Spring 2011.3 (2013) Web March 2012.

Museum Registration Methods: $5^{\text {th }}$ Edition. Eds. Rebecca A. Buck and Jean Allman Gilmore. Washington, AAM Press. 2010. Print.

Musée McCord d'histoire canadienne. Formes Et Modes: Le Costume à Montréal Au XIXe Siècle $=$ Form and Fashion: Nineteenth-Century Montreal Dress. Ed. Jacqueline Beaudoin-Ross. Montréal, Québec: Musée McCord d'histoire canadienne, 1992. Print. 
"New First at Ryerson.” Globe \& Mail. April 30, 1985, n.p. Print.

O'Connor, Eileen. "Dress Reform and Mail Order." Collections Canada Archives. n.d.Web, Sept. 2011.

Ohio State University Historic Costume \& Textiles Collection. Ohio State University, n.d. Web, June 2012.

Old Clothes, New Looks: Second Hand Fashion. Eds. Alexandra Palmer and Hazel Clark. New York: Berg, 2005. Print.

Palmer, Alexandra. "'A Bomb in the Collection': Researching and Exhibiting Early 20thCentury Fashion.” Textile Conservation: Advances in Practice. Eds. Frances Lennard and Patricia Ewer. New York: Butterworth-Heinemann, 2010. 41-48. Print.

--- "The Association of Canadian Couturiers." Fashion: A Canadian Perspective. Ed. Alexandra Palmer. Toronto: University of Toronto Press, 2004. 90-112. Print.

---. "Form Follows Fashion: A Motorcoat Considered." DRESS 12 (1986): 5-10. Print.

---. "New Directions: Fashion History Studies and Research in North America and England." Fashion Theory: The Journal of Dress, Body \& Culture 1.3 (1997): 297-312. Print. 
---. "Untouchable: Creating Desire and Knowledge in Museum Costume and Textile Exhibitions.” Fashion Theory 12.1 (2008): 31-64. Berg. Web. Jan. 2012.

Palmer, Alexandra. Couture \& Commerce: The Transatlantic Fashion Trade in the 1950s. Vancouver: UBC Press, 2001. Print.

---. Dior: A New Look, a New Enterprise (1947-57). First published by V\&A Publishing, 2009. ed. London: V\&A Publishing, 2009. Print.

Parliament of Canada. "Women's Right to Vote in Canada". Parlinfo. Web, Jan. 2013.

“About Pat McDonagh”. Pat McDonagh. n.d. Web, Jan. 2013.

Pearce, Susan M., ed. Interpreting Objects and Collections. New York: Routledge, 1994. Print.

---. Museums, Objects and Collections: A Cultural Study. London: Leicester University Press, 1992. Print.

Peers, Dale. Personal Interview: Seneca College Fashion Resource Collection, Toronto. 26 March 2012. 
---. "Re: Study Collection Project”. Message to Author 26 March 2012, Email.

Petrov, Julia. "Cross-Purposes: Museum Display and Material Culture.” Association for Religion and Intellectual Life. June (2012): 219-33. Print.

Pochna, Marie France. Dior. New York: Assouline, 2004. Print.

Prown, Jules David. "Mind in Matter: An Introduction to Material Culture Theory and Method." Winterthur Portfolio 17.1 (1982): 1-19. Print.

Putnam, James. Art and Artifact: The Museum as Medium. London: Thames \& Hudson, 2001. Print.

Reffes, Ellen. “Clothing Reveals Societies' History”. Ryersonian, February 2, 1979. 4. Print.

RISD Museum of Art, Rhode Island School of Design n.d. Web. Sept. 2012.

Royal Ontario Museum, Costume \& Textile Collection. n.d. Web. Nov. 2012.

Ryerson Fashion Research Collection Donation Binders, 1981-2009. Print.

Ryerson School of Fashion Archives. Library Archives, Folders 1949-1995. Print. 
Routh, Caroline. In Style: 100 Years of Canadian Women's Fashions. Toronto: Stoddart Publishing Co. Ltd., 1993. Print.

Sauro, Claire. "Re: Drexel Historic Costume Collection”. Message to Author 31 July 2012. Email.

School of the Art Institute of Chicago Fashion Resource Center. SAIC. Web, May 2012.

Schwartzman, Tamsen. "Imprints of the Body: An Interview with Tanya Marcuse." Fashion Projects: On Fashion and Memory. 3: 34-41. Print.

Seneca College Fashion Resource Centre. Seneca College, n.d.Web, Jan. 2013.

Sepulveda dos Santos, Myrian. "Museums and Memory: The Enchanted Modernity.” Journal for Cultural Research 7.1 (2003): 27-46. Print.

Skov, Lise, and Marie Melchior. "Research Approaches." Berg Encyclopedia of World Dress and Fashion 10.1 (2010) Web, Jan. 2012.

Sontag, Susan. On Photography. New York: Farrar, Straus and Giroux, 1977. Print.

"Spotlighting Ryerson Institute of Technology...a good neighbor of the north". McCall's School Stylist. Spring 1954:16-17. Print. 
Stallybrass, Peter. "Worn Worlds: Clothes, Mourning and the Life of Things." The Yale Review 81.2 (1993): 35-50. Print.

Starn, Randolph. “A Historian's Brief Guide to New Museum Studies.” The American Historical Review 110.1: 68-98. Print.

Strenge, Gayle. "Re: Ohio State University Historic Costume \& Textiles Collection”. Message to Author, 9 July 2012. Email.

Steele, Valerie. "Fashion Revolution." Berg Encyclopaedia of World Dress and Fashion (2012) Web, Jan.2012.

---. Fifty Years of Fashion, New Look to Now. New Haven: Yale University Press, 1997. Print.

---. "A Museum of Fashion is More than a Clothes-Bag." Fashion Theory: The Journal of Dress, Body \& Culture 2.4 (1998): 327-36. Print.

---. "Museum Quality: The Rise of the Fashion Exhibition." Fashion Theory 12.1 (2008): 730. Berg. Web, Jan. 21,2011.

Steele, Valerie. Personal Interview, FIT Museum, New York. July 17, 2012. 
Stevenson, N. J. “The Fashion Retrospective.” Fashion Theory 12.2 (2008): 219-36. Print.

Strenge, Gayle. "Re: Ohio State University Study Collection". Message to Author. 9 July 2012, Email.

Suddon, Alan. Memo to file: Appraisal of Garments donated by Linda Lewis 1988; Ryerson Fashion Research Collection Donation Binder 1981-1989. Print.

Suddon, Alan. “Going, Going, Gone.” Costume Society of Ontario Newsletter. Volume 9, Number 1, March 1979. Ed. Alan Suddon, Print.

Taylor, Lou. "Doing the Laundry? A Reassessment of Object-Based Dress History." Fashion Theory: The Journal of Dress, Body \& Culture 2.4 (1998): 337-58. Print.

Taylor, Lou. Establishing Dress History. New York: Manchester University Press, 2004. Print.

---. The Study of Dress History. New York: Manchester University Press, 2002. Print.

“The Costume Institute”. The Metropolitan Museum of Art, n.d.,Web, Jan. 2012. 
“The Soul of a Gown”. Advertisement for The Robert Simpson Company Limited. Toronto Blue Book 1906. Reprinted in the Costume Society of Ontario Newsletter, Volume 10 Number 1, April 1980: 13. Ed. Alan Suddon. Print.

Thompson, Eleanor. "Museum Collections of Dress and Fashion." Berg Encyclopedia of World Dress and Fashion 10.5: Global Perspectives (2010) Web, Nov. 2012.

The School of Fashion. "2011-2012 Maggy Reeves Fashion Design Award in the School of Fashion”. FCAD Application pdf, Web, Jan. 2013.

Tortora, Phyllis C. "Introduction to Demographic and Social Influences." Berg Encyclopaedia of World Dress and Fashion 3.2 (2010) Web, Nov. 2012.

Tran Lé, Julie. “Today in Met History: December 13.” Met Museum Dec.13, 2011. Web, Nov. 2012.

Turnbull Caton, Susan. "Fashion and War in Canada." Fashion: A Canadian Perspective. Ed. Alexandra Palmer. Toronto: University of Toronto Press, 2004. 249-269. Print.

University of Alberta. "Clothing and Textiles Collection Booklet". Undated [1999]. N.P., Print. 
University of Alberta. "Acquisitions Strategy - Clothing and Textiles Collection”. November 20, 2011. Web, June 2012.

University of Alberta Museums. University of Alberta, n.d. Web. Feb. 2013.

Vogel, Carol. "Brooklyn Museum's Costume Treasures Going to the Met”, The New York Times December 16, 2008. Web, Jan. 2013.

“Who's Who in Canada 1975-76: An Illustrated Biographical Record of Men and Women of the Time". Eds. Terry Hughes, Hugh Fraser and Terry M. Whelpton. Toronto: International Press Ltd., 1975. Print.

Wilson, Elizabeth. Adorned in Dreams. London: Virago Press, 1985. Print.

Wilson, Elizabeth, and Lou Taylor. Through the Looking Glass: A History of Dress from 1860 to the Present Day. London: BBC Books, 1989. Print.

Ziegert, Beate. "Items of historic value in the Fashion Department of Ryerson Polytechnical Institute". Undated memo to file: 1981. Ryerson Fashion Research Collection Donations Binder 1981-1989. Print. 